\title{
Integration of remote sensing, GIS and 2D resistivity methods in groundwater development
}

\author{
Gabriel Efomeh Omolaiye ${ }^{1} \cdot$ Ilesanmi Michael Oladapo $^{2} \cdot$ Adebowale Elijah Ayolabi $^{3} \cdot$ Rotimi Peter Akinwale $^{4}$. \\ Akinpelumi Adewale Akinola $^{5} \cdot$ Kayode Lanre Omolaye $^{6,7}$. Oluseun Adetola Sanuade ${ }^{8}$ (D)
}

Received: 25 September 2019 / Accepted: 28 April 2020 / Published online: 11 May 2020

(c) The Author(s) 2020

\begin{abstract}
An integration of remote sensing, geographical information system (GIS) and 2D resistivity techniques was used to evaluate the groundwater potential of Obafemi Owode local government area (LGA) in Ogun State, southwestern Nigeria. A composite Landsat 7 image was used to produce land use and lineament of the study area. Advanced space-borne thermal emission and reflection radiometer (ASTER) data were used to generate slope and drainage density. The study adopted modified drastic model for groundwater potential, integrating six parameters which are land use, lineament density, slope, drainage density, geology and soil map. The contribution of each theme to groundwater potential was weighted and ranked using ArcGIS 10.2 software. The groundwater potential zone of the study area delineated five distinct zones which include very high $\left(196.39 \mathrm{~km}^{2}\right)$, high $\left(334.64 \mathrm{~km}^{2}\right)$, moderate $\left(481.76 \mathrm{~km}^{2}\right)$, low $\left(298.46 \mathrm{~km}^{2}\right)$ and very low $\left(95.73 \mathrm{~km}^{2}\right)$. Eight zones were delineated for further study. A total of 4.8 line $\mathrm{km}$ of $2 \mathrm{D}$ resistivity profiles were investigated in one of the designated zones labeled "area D" based on the groundwater potential map. Pole-dipole and dipole-dipole arrays used reveal five geoelectric layers within the study area. The 2D inverse models of resistivity variation with depth suggest the occurrence of potential carbonate and silicate aquifers. To verify the interpreted results within the "high" groundwater potential zone, a well was drilled on traverse 1. A potential water-bearing aquifer was encountered at a depth of $75 \mathrm{~m}$. The groundwater potential map of the study area was tested with five existing wells, and the result was impressive. The outcomes from this study show that the high potential zones would play a key role in future expansion of drinking water and irrigation development in the study area.
\end{abstract}

Keywords GIS $\cdot$ Remote sensing $\cdot$ Groundwater geophysics $\cdot$ Resistivity

\section{Introduction}

Oluseun Adetola Sanuade

sheunsky@gmail.com

1 Geoslice Solution Limited, Lagos, Nigeria

2 Marine Geoscience Department, Federal University of Technology Akure, Ondo State, Nigeria

3 Mountain Top University, Lagos State, Nigeria

4 Rockmode Geosciences, Lagos State, Nigeria

5 Arctic Spatials Ltd, Lagos State, Nigeria

6 Golden Citadel Nigeria Limited, Allen Avenue, Ikeja, Lagos State, Nigeria

7 Geospatial Research Limited, Lagos State, Nigeria

8 Boone Pickens School of Geology, Oklahoma State University, Stillwater, OK 74078, USA
It is globally acknowledged that the world's freshwater resources are limited and cannot continue forever to sustain the rising demands we make on them. Obafemi Owode local government area of Ogun State, Nigeria, is not left out in this global phenomenon. There is an extreme variation in the distribution of water resources in this area. The availability of surface water largely depends on rainfall and regional morphology of the area. Due to the limitation in the availability of surface water, there is a need to explore the groundwater resources which are more reliable, but the occurrence needs to be accessed through evaluation using integration of techniques that can resolve the hidden subsurface hydrogeological heterogeneity.

Groundwater is the most important source of water, and it accounts for almost two-third of the freshwater resources of the world in addition to polar ice caps and glaciers (Freeze 
and Cherry 1979). In Nigeria, the population has been increasing at a rate of about 3\% yearly since 1991 (FOS 2019) and the supply of water has not been following the same trend. Water supply coverage of Nigeria has remained at $57 \%$ for a very long time (Olasehinde 2010). This percentage can be greatly improved by the combined use of surface and groundwater resources. One of the limiting factors is the poor knowledge about the possibility sources in Nigeria (Olasehinde 2010).

The studies of groundwater have become essential not only for searching for zones of groundwater, but to also monitor and conserve this important natural resource. To locate aquifer, it is essential to determine the quality of groundwater and its physical characteristics. To achieve this, reliable and standard methods are test drilling and stratigraphy analysis. However, this analysis is known to be costly, consumes more time and requires skilled manpower (Sander et al. 1996).

There are many conventional methods for the exploration and preparation of groundwater potential map of an area, such as geological, geophysical and hydrogeological methods (Shahid et al. 2000; Srivastava and Bhattacharya 2006; Talabi and Tijani 2011; Aizebeokhai and Oyeyemi 2017; Oyeyemi et al. 2018; Nwachukwu et al. 2019; Mehmood et al. 2020). The commonly used methods are the geophysical techniques, but they could be time-consuming, especially where large areas are to be covered (Fenta 2015; Oyeyemi et al. 2018). However, remote sensing and geographic information system (GIS) provide spatial, spectral and temporal availability of data that have the capability to cover large and inaccessible areas within a short period of time and serve as very useful tool to assess, monitor and manage groundwater resources (Murthy 2000; Khan and Moharana 2002; Hoffman 2005; Jha et al. 2007; Tweed et al. 2007; Machiwal et al. 2011; Al-Bakri and Al-Jahmany 2013; Singh et al. 2013; Elbeih 2015; Thakur et al. 2017; Acharya et al. 2019; Muchingami et al. 2019; Shailaja et al. 2019; Kumar et al. 2020; Sangay et al. 2020). Although remote sensors are not capable of detecting groundwater directly, it uses various surface features generated from satellite imagery, such as geology, landforms, rainfall, soil, land use or land cover, surface water bodies which serve as indicators for areas with high groundwater potentials (Todd 1980; Al-Bakri and AlJahmany 2013; Elbeih 2015).

GIS also provides the capability in the management and integration of large volume of spatial and temporal data efficiently. This will help in narrowing down the potential areas for conducting detailed hydrogeological and geophysical survey on the ground, and ultimately to locate the site for drilling. Therefore, the integration of remote sensing and GIS provides an important tool in the successful evaluation of groundwater prolific zones on a regional scale.
In addition, in an area having a complex geology like the study area, the use of geophysical method in groundwater delineation is very important, as it helps to understand the hidden subsurface hydrogeological heterogeneities. One of the geophysical methods most widely used for groundwater exploration is the electrical resistivity method (Abdullahi and Iheakanwa 2013; Kayode et al. 2016; Oyeyemi et al. 2018; Nwachukwu et al. 2019; Mehmood et al. 2020). 2D electrical resistivity method measures both the vertical and lateral variation in electrical resistivity of the subsurface, thereby providing valuable information about the subsurface. The electrical resistivity of the subsurface depends on the rock matrix (mineral or rock composition), porosity, fluid saturating the pore spaces, degree of saturation and cementation among other factors (Archie 1942); therefore, it can be used in groundwater assessment, engineering, environmental and mineral exploration (Reynolds 1997). However, several factors might be responsible for electrical resistivity signatures and there may be a need to constrain interpretation with other available data.

Therefore, this study adopted the integration of remote sensing and GIS techniques to narrow down the target areas for conducting detailed geophysical and hydrogeological surveys, thereby reducing cost of groundwater exploration, and also to create database for future groundwater development in Obafemi Owode LGA of Ogun State.

\section{Physiography and geology of the study area}

The study area is located in Ogun State, southwestern Nigeria. It lies between latitude $6^{\circ} 41^{\prime} 38^{\prime \prime}$ to $7^{\circ} 14^{\prime} 14^{\prime \prime}$ and longitude $3^{\circ} 16^{\prime} 18^{\prime \prime}$ to $3^{\circ} 48^{\prime} 51^{\prime \prime}$ with area coverage of approximately $1407.84 \mathrm{~km}^{2}$ (Fig. 1). The climate in Ogun State follows a tropical pattern with the dry season beginning in December and ending in February, followed by nine months of raining season. The average annual rainfall ranges from $128 \mathrm{~cm}$ in the southern parts of the State to $105 \mathrm{~cm}$ in the northern areas. The mean monthly temperature varies from $23{ }^{\circ} \mathrm{C}$ in July to about $32{ }^{\circ} \mathrm{C}$ in February. The northern part of the state is primarily composed of derived savannah vegetation, the central part is, however, made up of rain forest belt, while the southern part of the State is mangrove swamp (Ogun State Water Corporation 2010).

\section{Geologic setting of Dahomey basin}

The Dahomey basin is an inland/coastal/offshore basin and extends from the southeastern part of Ghana through Togo and the Republic of Benin to southwestern Nigeria (Fig. 2). The basin is separated from the Niger Delta by a subsurface basement high known as the "Okitipupa ridge." The offshore part of the basin is not well defined. Sediments were 


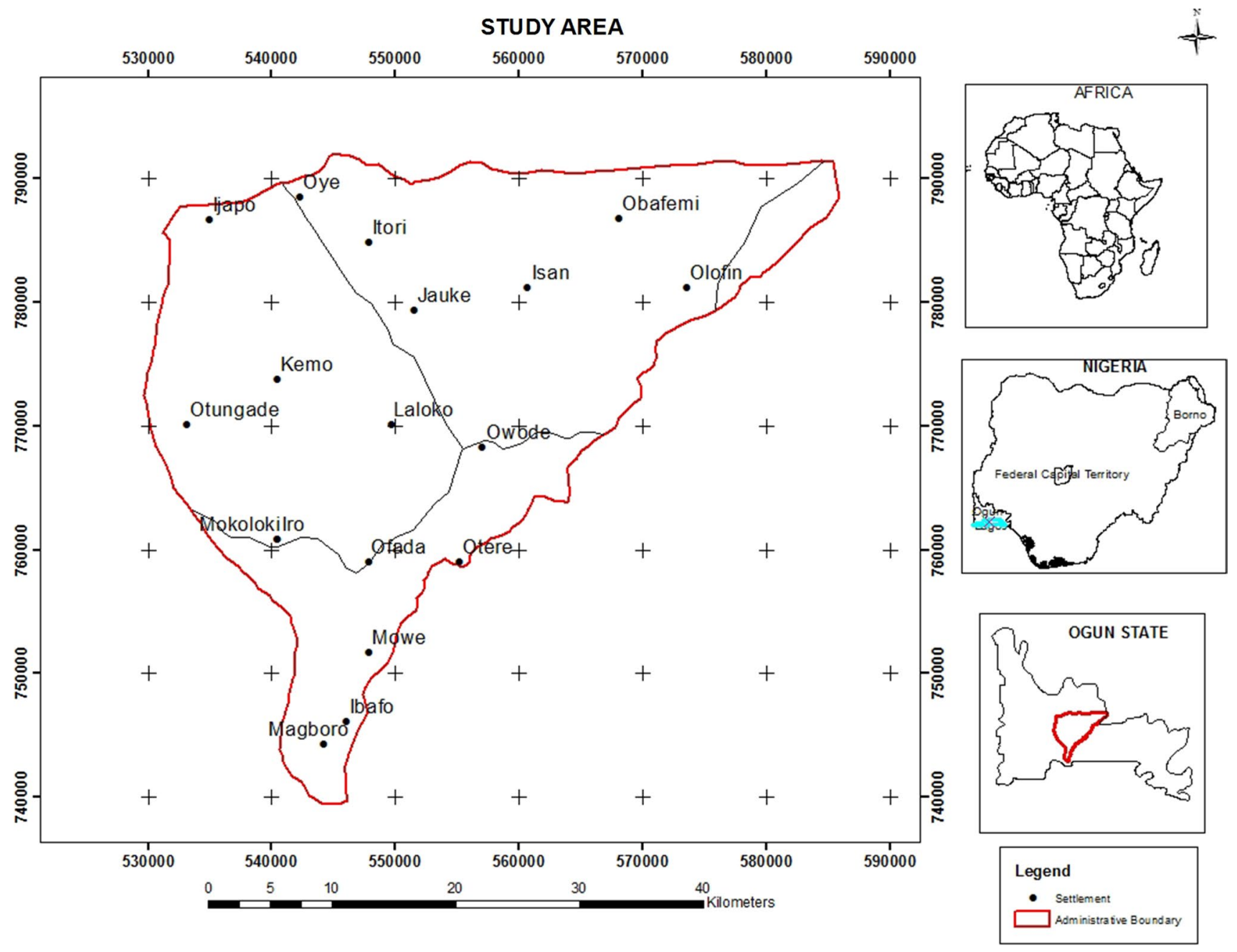

Fig. 1 Map of Obafemi Owode local government area of Ogun State

deposited in an east-west (E-W) direction. However, geology is fairly well defined in the republic of Benin part of the basin (Billman 1976; De Klasz 1977). Cretaceous strata in the onshore part are approximately $200 \mathrm{~m}$ in thickness (Okosun 1990). The thickness of the offshore sequence is $1000 \mathrm{~m}$ and is composed of sandstones and black fossiliferous shale. This sequence was reported and dated to be pre-Albian to Maastrichtian (Billman 1976). The Cretaceous has been divided into two geographic zones which are the north and south. The sequence in the north is made up of basal sands that progressively become clay beds having some intercalation of lignite and shale. The stratigraphy of the sequence in the south is more complicated having limestone and marl beds as their major facies.

Sedimentation in the northern zone began during the Maastrichtian and situated inland close to the periphery of the basin. During this time, a thin sequence $(<200 \mathrm{~m})$ of unconsolidated sand, grits, silts, clay and shale was deposited. This sequence overlies the basement having the transitional facies being marked by a basal conglomerate or white to gray sandy and kaolinitic clays derived as degradation products from the surrounding Precambrian rocks. However, the oldest sediments in the southern zone are made up mainly of loose sands, grits, sandstone and clay with interbedded shale which progressively become shalier. The age of these sediments is Albian and possibly Neocomian (Omatsola and Adegoke 1981).

The conglomerates in the basal part were defined from both surface and subsurface data (Jones and Hockey 1964; Omatsola and Adegoke 1981). The succession in the Cretaceous reveals lithological changes which have been expressed in terms of formal and informal lithostratigraphic nomenclature by several workers in the basin (Fig. 3).

The Dahomey basin is a product of Albian rifting of the Gondwanaland with the resultant opening on the south Atlantic in its three domains (Omatsola and Adegoke 1981; Storey 1995; Mpanda 1997). Burke and Dewey (1972) described the basin subsidence during the lower 


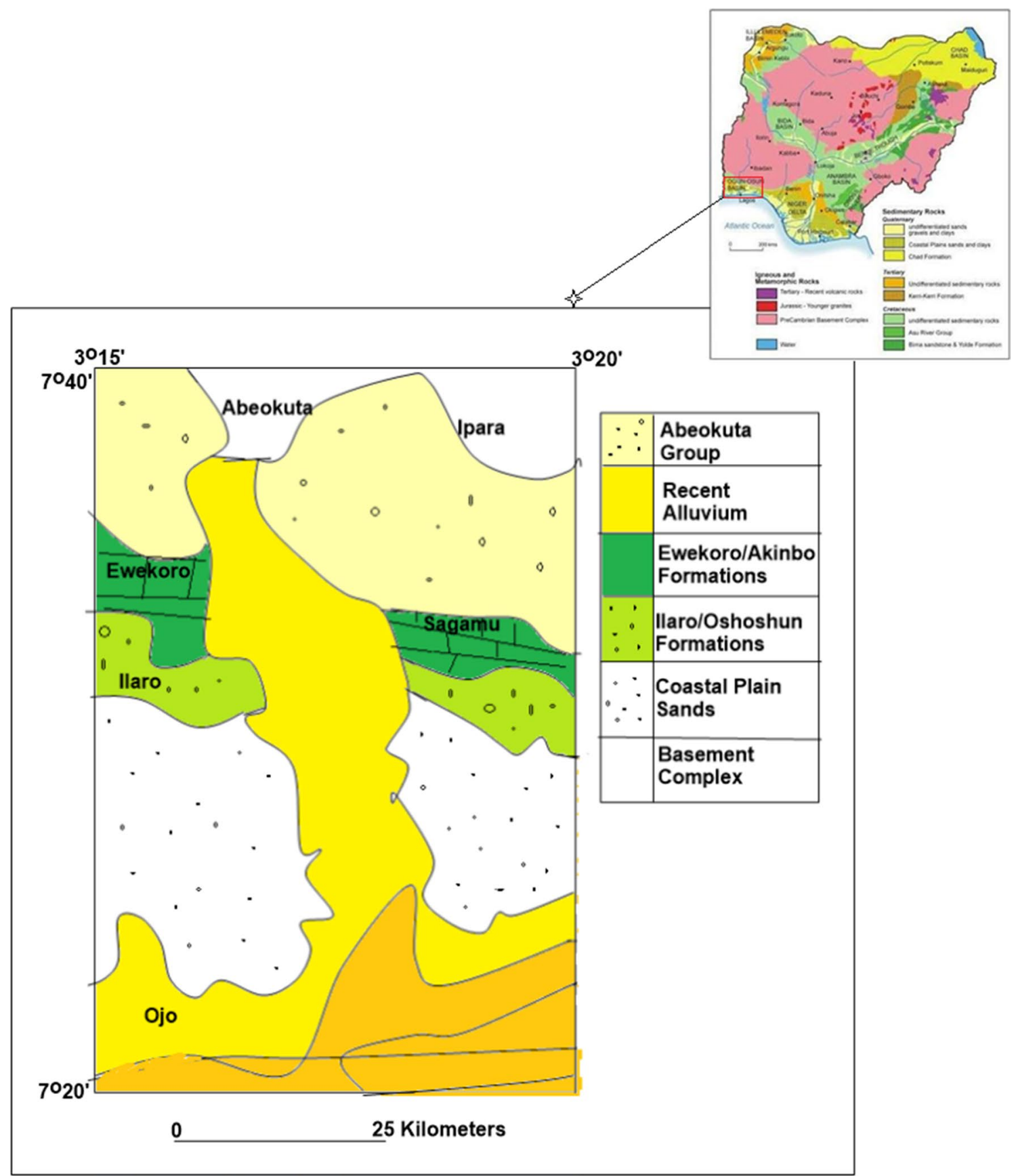

Fig. 2 Geological map of the study area (modified after Agagu 1985). The map in the upper part of the figure shows the geological map of Nigeria

cretaceous along the RRR triple junction. This resulted in the deposition of a thick pile of continental grits and pebbly sands over the entire basin (Omatsola and Adegoke 1981). Structurally, the basin is bounded in the east and west by faults and tectonic structure associated with the landwards extension of the chain and romance fracture zone, respectively. The evolution of the Dahomey basin is best represented by a combination of continental drift tectonics and crustal subsidence. The basement rocks of the basin were tilted southward and block-faulted to form a series of horst and grabens (Omatsola and Adegoke 1981).

The geothermal gradient of the Dahomey basin is generally high, about $40^{\circ} \mathrm{C} / \mathrm{km}$ (Avbovbo 1978). This is as a result of high heat flow $\left(59.46 \pm 0.92 \mathrm{MWM}^{-1}\right)$ recorded 
Fig. 3 Stratigraphic column in the Dahomey basin. This stratigraphic division was made by several workers in the basin

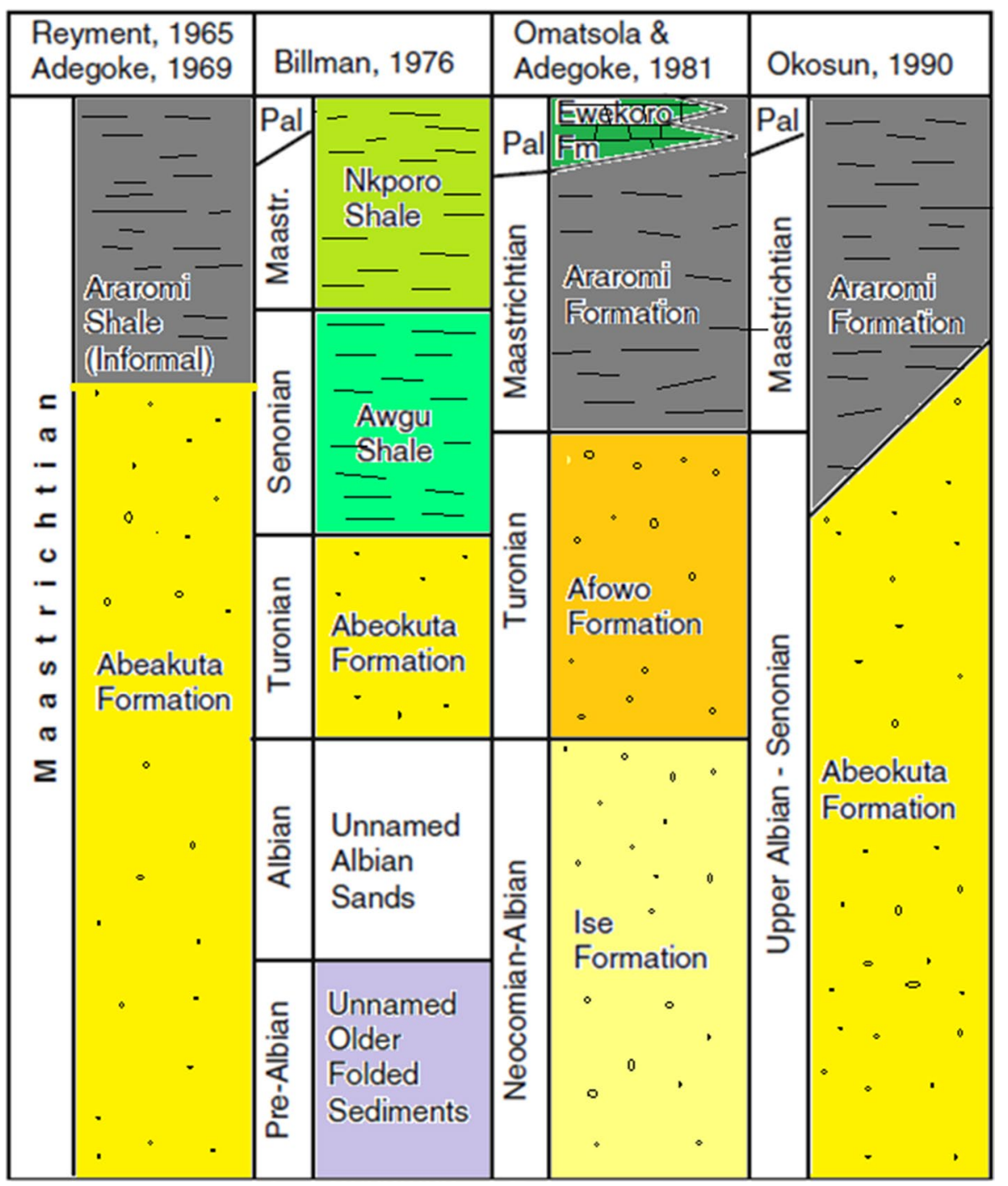

across this part of the West African margin (Herman et al. 1977). This means that the area is underlain by an anomalously thin lithosphere. This concept of a thermally controlled isostatic subsidence of the basin was proposed (Onuoha and Ofoegbu 1988).

The stratigraphy of the eastern Dahomey basin was classified by different authors with different conclusions, thereby making it very controversial. This is because different names and ages have been reported for the same formation by different workers (Jones and Hockey 1964; Omatsola and Adegoke 1981) among others. However, a classification of the Dahomey basin lithology from the lowest to the topmost unit is in the following order: Abeokuta group which is made up of Araromi member, Afowo member and Ise member; Ewekoro Formation; Akinbo Formation; Oshosun Formation; Ilaro Formation and sands of the coastal plain. Beneath this profile of units or formations lies the basement complex which is directly under the Abeokuta formation (Fig. 4).

\section{Materials and methods}

Remote sensing and geographical information system (GIS) techniques were employed for reconnaissance survey at Obafemi Owode LGA to delineate potential zones of groundwater, while $2 \mathrm{D}$ resistivity survey was conducted within one of the potential groundwater zones delineated by the integration of GIS and remote sensing. 


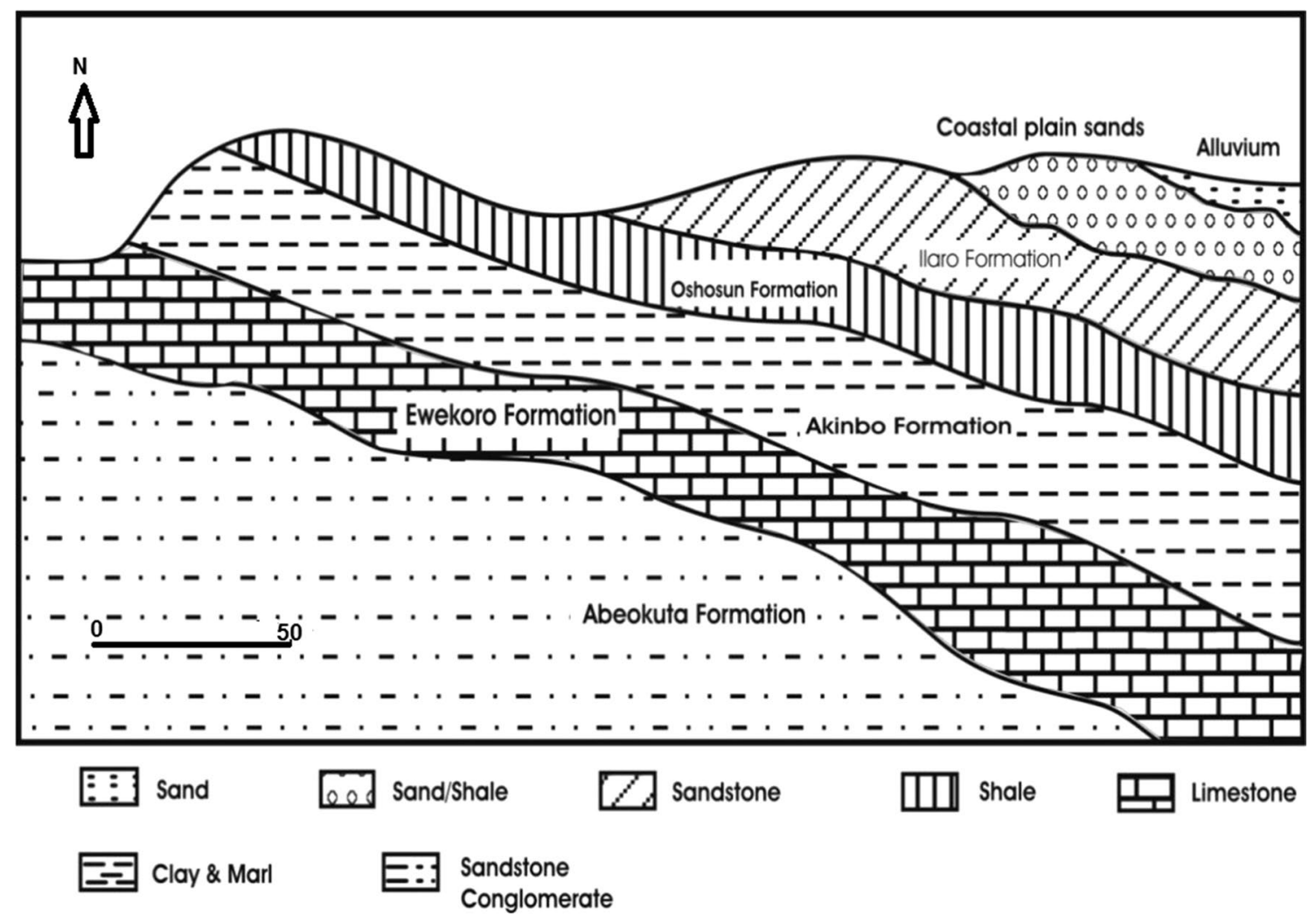

Fig. 4 Litho-stratigraphy of Dahomey basin as exposed in the southwest part of the basin (Omatsola and Adegoke 1981)

\section{GIS and remote sensing}

A GIS system involves acquisition of geometric and attribute data. Researchers around the world have used remote sensing and GIS techniques to study groundwater potentials as well as to aid further exploration, which are mainly modeling-dominated context (Al-Bakri and Al-Jahmany 2013; Singh et al. 2013; Elbeih 2015; Thakur et al. 2017; Acharya et al. 2019; Muchingami et al. 2019; Shailaja et al. 2019; Kumar et al. 2020; Sangay et al. 2020). For effective groundwater exploration and exploitation, it is important to study the different parameters in an integrated approach. The integration of multiple data sets, with various indications of groundwater availability, can decrease the uncertainty and lead to "safer" decisions (Sander et al. 1996; Singh et al. 2013; Kumar et al. 2020). This will help in narrowing down the target areas for conducting detailed hydrogeological and geophysical survey on the ground, and ultimately to locate the site for drilling. El Hadanai et al. (1993) shows that ground water development in Morocco using image interpretation as a major technique reduces the number of drill holes and drill costs incurred on geophysical survey. Such model as DRASTIC model has been successfully used for exploring groundwater contamination as well as groundwater potentials (modified
DRASTIC) using surface features as factors that affect groundwater accumulation.

Hydrogeologic, geologic, soil and Landsat DEM data were employed in this study to determine the potential of groundwater (geology, soil, land use, lineament, slope and drainage). Modified DRASTIC index/model was adopted for this study. This model was founded by the United States Environmental Protection Agency (USEPA) as a standardized approach for evaluating pollution of groundwater potentials (Aller et al. 1987). The explanation of the model is given thus:

$\mathrm{D}=$ depth of water from the ground surface to the water table in unconfined aquifer and to the bottom of the confining layer in confined aquifer; $\mathrm{R}=$ net recharge, i.e., the total quantity of water which is applied to the ground surface and infiltrates to reach the aquifer; $\mathrm{A}=$ aquifer media, i.e., consolidated or unconsolidated rock which serves as an aquifer (such as sand, gravel, and limestone); $\mathrm{S}=$ soil media, the uppermost portion of the vadose zone characterized by a significant biological activity; $\mathrm{T}=$ topography and slope variability of the land surface; $I=$ impact vadose zone is the zone above the water table which is unsaturated or discontinuously saturated; $\mathrm{H}=$ hydraulic conductivity is the ability of the aquifer materials to transmit water.

The equation for DRASTIC index is 
$\mathrm{DrDw}+\mathrm{RrRw}+\mathrm{ArAw}+\mathrm{SrSw}+\mathrm{TrTw}+\mathrm{IrIw}+\mathrm{CrCw}=\mathrm{GPP}$

where $r=$ ratings; $w=$ weight; and GPP=groundwater pollution potentials.

The weight and the ratings constitute the significant part of the model.

Weights Each of the factors has been evaluated with respect to their relative importance and was assigned a relative weight ranging from 1 to 5 . The most significant factors make the weight of 5, and the least significant factor makes the weight of 1 (Dee et al. 1973).

Ratings Each range for each DRASTIC parameter is evaluated with respect to others to determine the relative significance of each range with respect to pollution potential.

DRASTIC model has been used within the GIS context to map out groundwater potential in many areas. Geology, drainage density, soil types, slope, land use and geomorphology are the factors mostly considered, with the spatial overlay concept replacing the initial DRASTIC factors with those factors that influence groundwater occurrence. This approach is referred to as the modified DRASTIC model or simply the DRASTIC-based model. Modified DRASTIC model is basically an overlay scheme with a focus on the factors that influence groundwater occurrence which are dependent on surface characterization.

According to Khairul et al. (2000), modified DRASTIC model is

$$
\begin{aligned}
\mathrm{GP}= & \mathrm{Ge}(r) \mathrm{Ge}(w)+\mathrm{St}(r) \operatorname{St}(w)+\mathrm{Lu}(r) \mathrm{Lu}(w) \\
& +S(r) S(w)+D(r) D(w)+L(r) L(w)
\end{aligned}
$$

whereGP = groundwater potentials; $\mathrm{r}=$ ratings; $\mathrm{w}=$ weight; $\mathrm{Lu}=$ land use/cover; $\mathrm{Ge}=$ geology; $\mathrm{S}=$ slope; $\mathrm{D}=$ drainage density; $\mathrm{St}=$ soil type; $\mathrm{L}=$ lineament (substituted for geomorphology).

All the thematic layers were subjected to image processing, and integration was carried out in ENVI 5.0 and ArcGIS 10.2 environment for decision making (www.esri.com/softw are/arcgis; www.exelisvis.com/ProductsServices/ENVIP roducts/ENVI.aspx).

Modified DRASTIC model though does not use a standardized validation test for the aquifer, it provides an

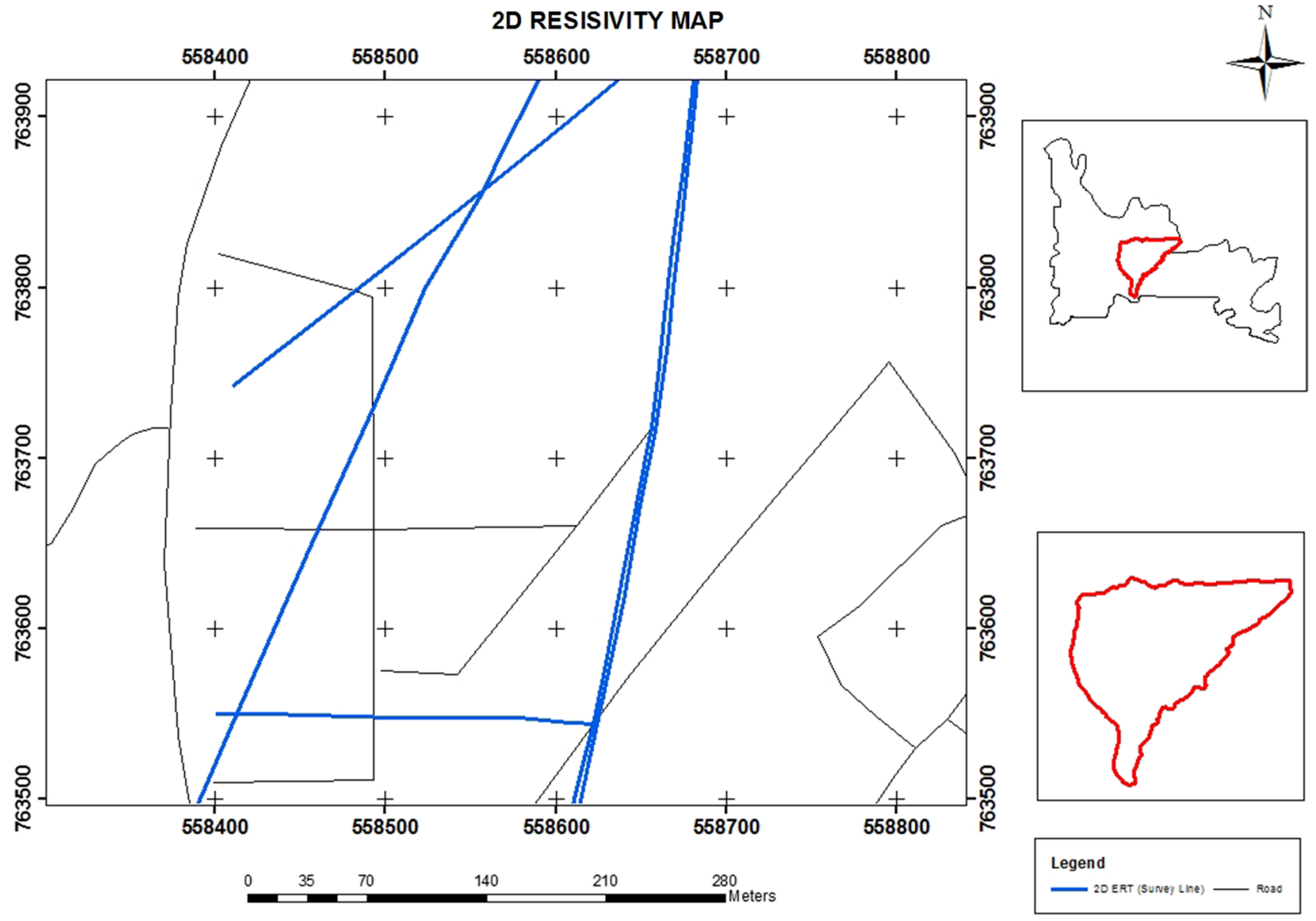

Fig. 5 Map of the 2D resistivity survey in the study area. The blue lines are the five traverses along which 2D resistivity measurements were taken 
approach to evaluate an area based on known conditions, hydrogeological parameters and, hence, inexpensive method to determine an area for further investigation.

\section{$2 D$ resistivity method}

The data acquisition for the 2D electrical resistivity imaging (ERI) survey was carried out with the aid of automated equipment (SuperSting R8). The equipment is a multi-electrode system in which multiple electrodes (84) were planted at electrode spacing of $2.5,5$ and $7 \mathrm{~m}$ on five traverses (Fig. 5). The electrode spacing determines the lateral coverage, and it is proportional to the depth of investigation but inversely proportional to the resolution of subsurface layers (represented as geoelectric layers). The automated multielectrode system is comprised of several electrodes connected to multi-core cables at current takeouts. The cables were connected to one another, and either ends were connected to a switch box. The switch box serves as an electrode selector in which it selects the two pairs of electrodes needed for each field resistivity reading. The advancement of equipment also made it possible to take multiple readings (on some arrays) at each current injection. The arrays employed for this study are dipole-dipole and pole-dipole configuration and have been selected to complement each other in terms of depth of penetration, signal-to-noise ratio, lateral coverage and resolution (Loke 1999).

The field data are considered as the apparent resistivity because of the several assumptions in its measurement and does not totally represent true subsurface resistivity. In order to estimate true resistivity, the apparent resistivity was subjected to inversion using the Earth Imager software (AGI 2009). Inversion of the resistivity data involves mapping from data space to model space, and it reconstructs the subsurface resistivity distribution from measured field data. The smooth model inversion (also known as Occam's inversion) algorithm was used (Sasaki 1992). The smooth model inversion finds the smoothest possible model whose

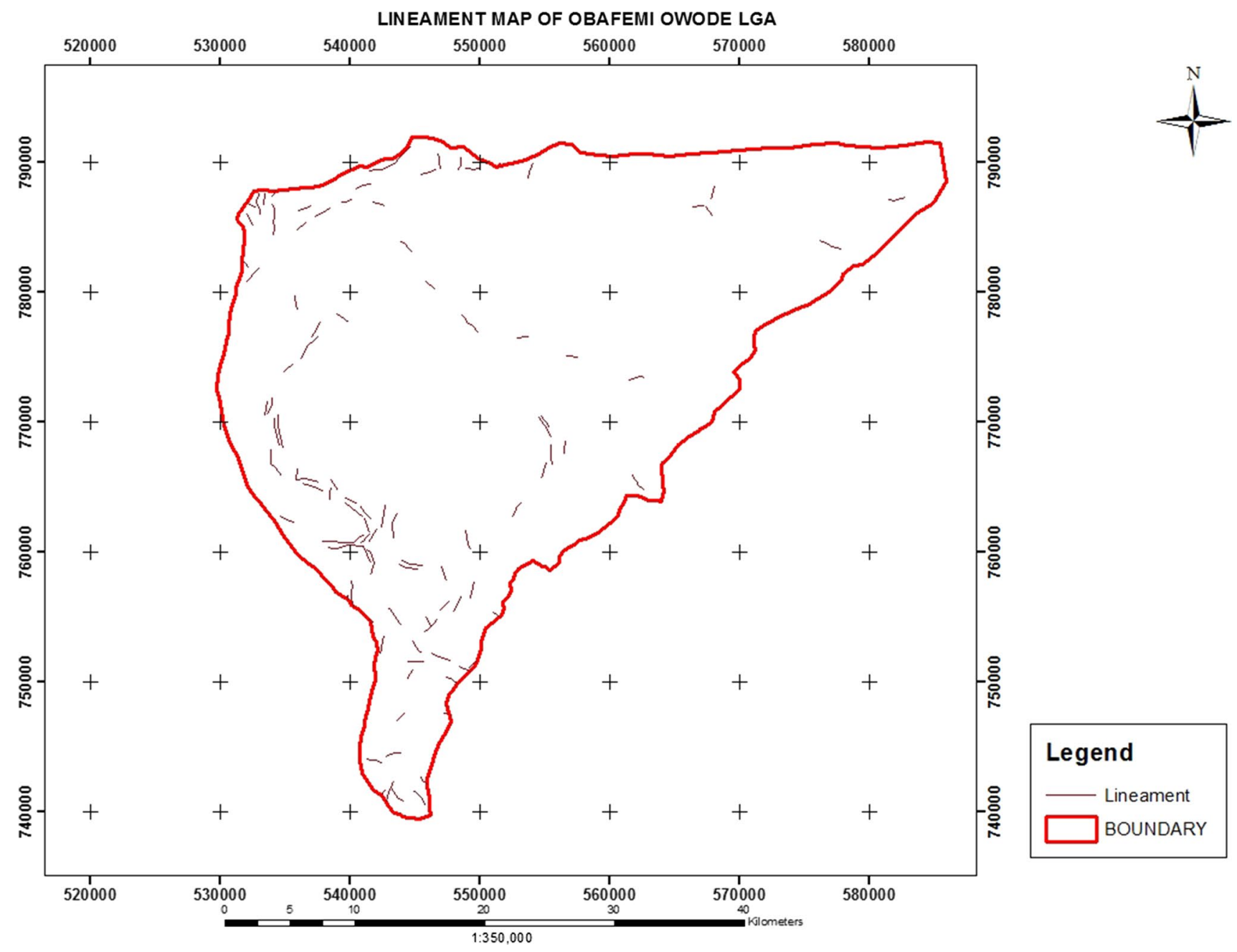

Fig. 6 Lineament map of Obafemi Owode LGA. The red color delineates the administrative boundary of the area 
response fits the data to a priori chi-squared statistic (AGI 2009). The result of the inversion is presented as a colorcoded 2D inverted electrical resistivity section. The resistivity (range) of each color is presented as a logarithmic color scale bar on the section, while the lateral and depth investigated are represented as the horizontal and vertical scale in meters, respectively.

The geographical setting of the State comprises Savannah land in the northwestern part of the State, suitable for cattle rearing and widespread fertile soil suitable for agriculture. There are also massive forest reserves, rocks, mineral deposits, lagoons, rivers and an oceanfront. Obafemi Owode LGA has the most dramatic increase in population in Ogun State with a population of about 200,000 in 2005 to a projection of over 2000,000 by 2025 (Ogun State Water Corporation 2010). Obafemi Owode LGA is situated in the sedimentary area of southwestern Nigeria which lies in the Dahomey Basin (Fig. 2).

\section{Data analysis and interpretation}

\section{GIS and remote sensing}

\section{Lineament and lineament density}

In groundwater exploration, the mapping of lineament is an essential component which cannot be ignored. Lineaments are surface manifestations of structurally controlled features, such as joints, straight course of streams and vegetation alignments (El Hadani 1997; Abdullahi et al. 2013). The Landsat ETM + of $30 \mathrm{~m}$ resolution having six bands $(1,2,3,4,5$ and 7$)$ was used. Preprocessing of the image was carried out by removing the spectral signature of the vegetation using red and near-infrared bands for better interpretation of geological features. The six bands were merged together to form a composite image in ENVI 5.0. The principal component analysis was performed on the image for

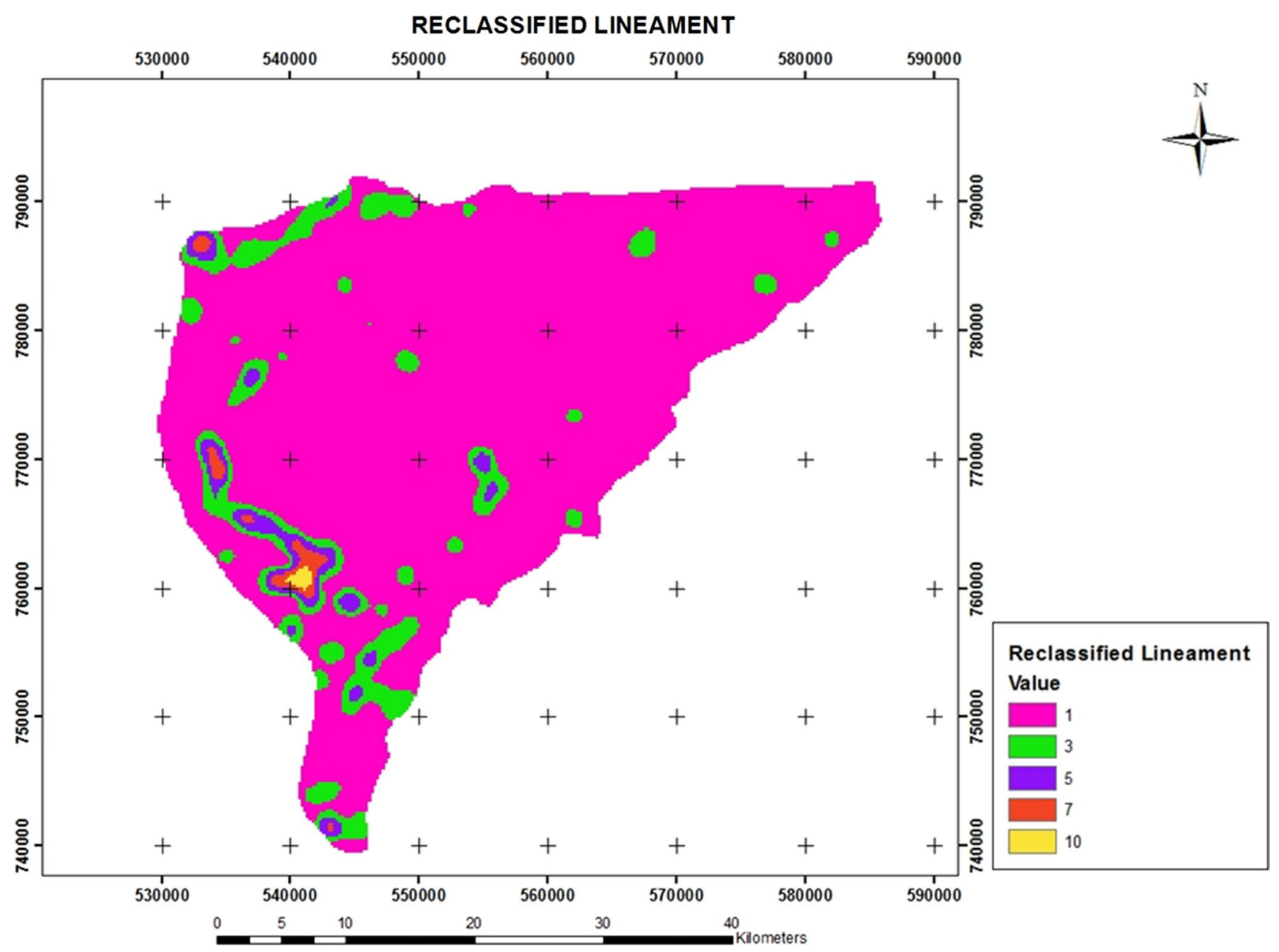

Fig. 7 Lineament density map of the study area. High rating of 10.0 signifies high density of lineaments, while low rating of 1.0 indicates low lineament density 
image enhancement. The automatic extraction of lineament was performed on the image (Fig. 6).

The extracted lineament was rasterized; hence, lineament density was generated. The analysis of lineament of an area when extracted from the remotely sensed data gives vital information on subsurface features that may control the movement and/or storage of groundwater.

There is an uneven distribution of lineaments within the study area. The two prominent directions identified are northeast-southwest (NE-SW) and northwest-southeast (NW-SE), while to a lesser extent E-W trend in the southern part of the survey area. Lineament density map is a measure of quantitative length of linear attribute per unit area which could infer the presence of groundwater. The presence of lineaments usually denotes a permeable zone. The lineament density of the study area of about $0.29 \mathrm{~km} / \mathrm{km}^{2}$ covers a total area of $1242.4 \mathrm{~km}^{2}(83.31 \%)$. The lineament density between 0.29 and $0.58 \mathrm{~km} / \mathrm{km}^{2}$ covers a total area of $121.3 \mathrm{~km}^{2}$
(8.62\%), between 0.58 and $0.87 \mathrm{~km} / \mathrm{km}^{2}$ with a total area of $30.10(2.14 \%)$, between 0.87 and $1.16 \mathrm{~km} / \mathrm{km}^{2}$ with a total area of $10.5 \mathrm{~km}^{2}(0.75 \%)$ and between 1.16 and $1.45 \mathrm{~km} /$ $\mathrm{km}^{2}$ with a total area of $2.2 \mathrm{~km}^{2}(0.16 \%)$. The greater the lineament density, the higher the probability of groundwater occurrence. Hence, high rating of 10.0 was assigned to area with high density of lineaments $\left(1.16-1.45 \mathrm{~km} / \mathrm{km}^{2}\right)$, while a low rating of 1.0 was assigned to the area of low lineament density (less than $0.29 \mathrm{~km} / \mathrm{km}^{2}$ ) (Fig. 7).

\section{Slope}

For each cell, the slope computes the maximum rate of change in value from its cell to its neighbors. ASTER DEM data with $30 \mathrm{~m}$ spatial resolution were used for the extraction of the slope of the study area. Radiometric and geometric corrections were carried out as part of preprocessing. The slope was obtained in degrees from the DEM using the

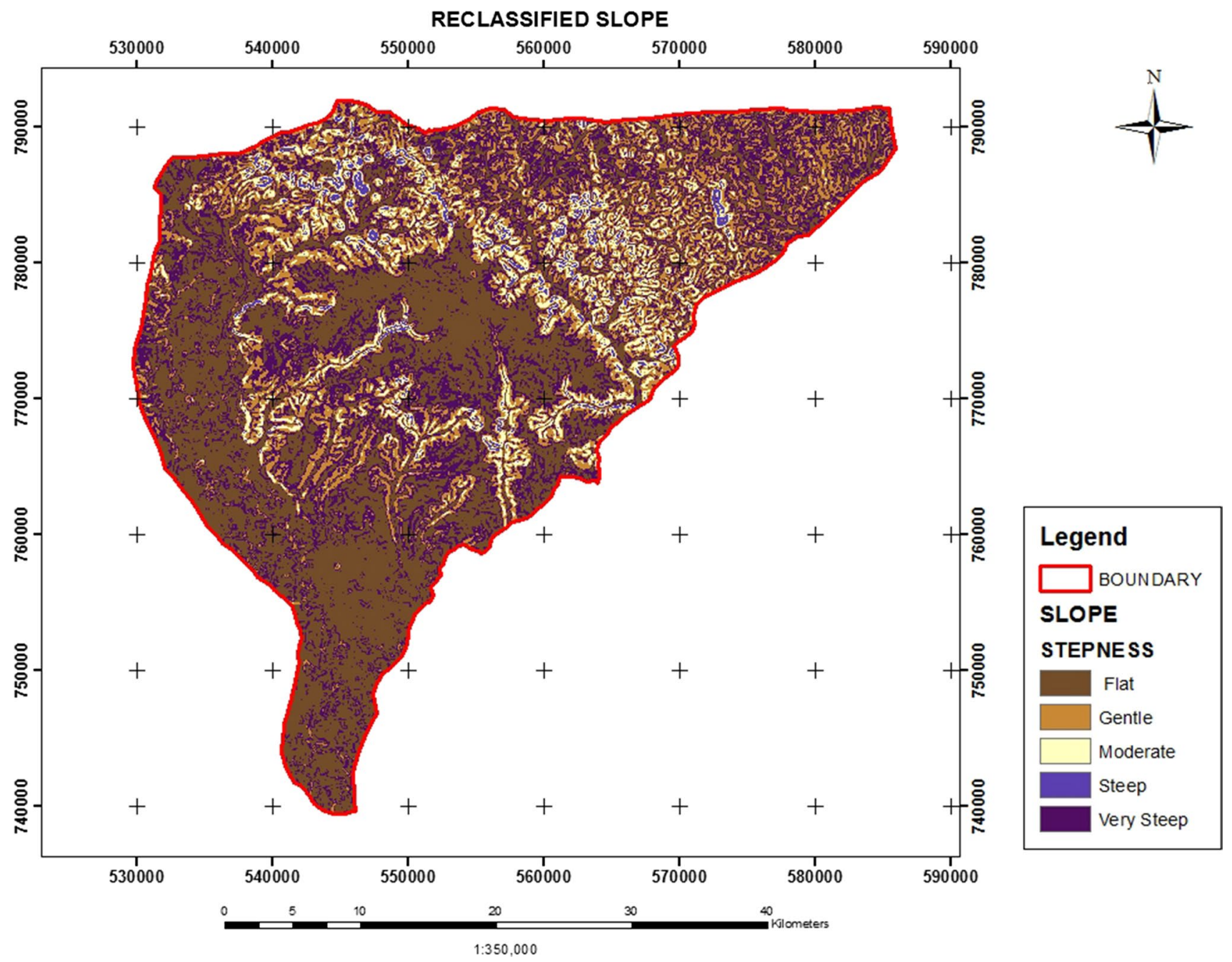

Fig. 8 Slope map of the study area. High rating of 10.0 indicates flat area, while low rating of 2.0 shows very steep area 
Table 1 Classification of slope in the study area

\begin{tabular}{llll}
\hline Slope type & Slope range $(\%)$ & $\begin{array}{l}\text { Area covered } \\
\left(\mathrm{km}^{2}\right)\end{array}$ & Percentage \\
\hline Flat & $<1.53$ & 573.2 & 40.74 \\
Gentle & $1.53-2.9$ & 426.3 & 30.3 \\
Moderate & $2.98-4.98$ & 278.1 & 19.77 \\
Steep & $4.98-8.04$ & 105 & 7.5 \\
Very steep & $>8.04$ & 23 & 1.64 \\
\hline
\end{tabular}

spatial analyst tools ArcGIS 10.2. The slope ranges were then rated and classified (Fig. 8). Slope is one of the factors controlling the penetration and revitalization of groundwater system; hence, the nature of slope alongside other geomorphic features can give a clue of groundwater potential zones in an area. In groundwater accumulation, the slope of an area plays a very significant role in terms of infiltration as well as runoff (Nag and Anindita 2011). Infiltration is inversely related to slope; hence, the slope was further classified into flat, gentle, moderate, steep and very steep. Therefore, surface runoff is low in a low slope area as this allows more time for rainwater infiltration into the subsurface and vice versa.

The slope in the study area ranges from less than 1.5 to about $19.5 \%$. The distribution of the slopes in the study area is an indication of varied degree of runoff and groundwater recharge.

Figure 8 is the slope thematic map of the study area. It shows the subdivision of slope in the entire area ranging from flat to very deep slope (Table 1).

From the classification shown in Table 1, the southern part of the study area is dominated by flat to gentle slopes which is an indication that about $80 \%$ of the study area was rated higher in terms of groundwater potentiality. The high rating of 10.0 was assigned to flat area, while a low rating of 2.0 was assigned to very steep area. There is a possibility of a flat area where the slope is low and has a

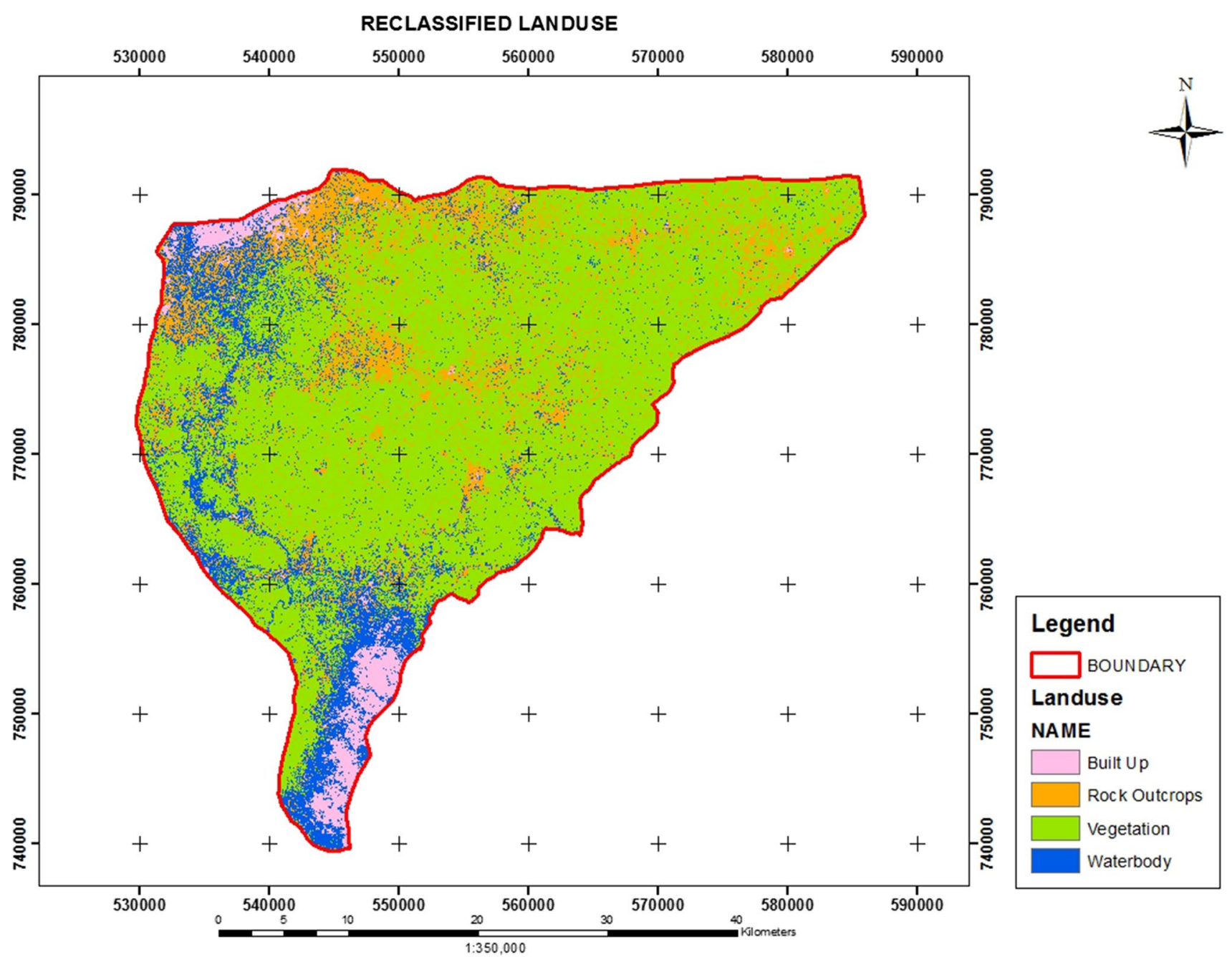

Fig. 9 Land use map of the study area. The dominant feature is vegetation covering an area about $65.7 \%$ of the total land use 


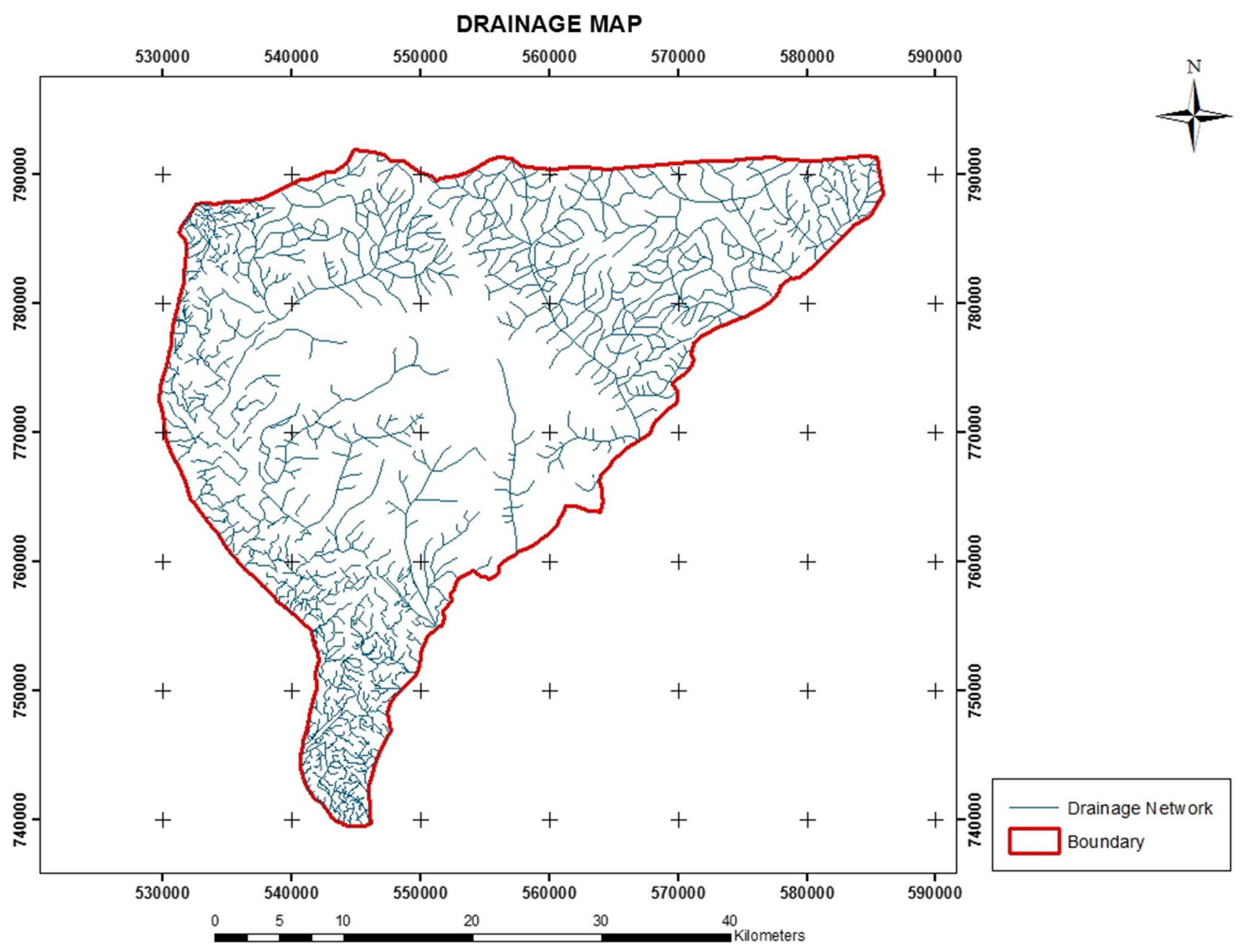

Fig. 10 Drainage map of the study area showing dendritic drainage systems. The red color signifies the boundary

high tendency of facilitating recharge and retaining rainfall, while steep areas with slope will have less infiltration and high runoff, i.e., groundwater accumulation is greater in flat area than steep area (Solomon and Quiel 2006).

\section{Land use/land cover}

The land use of the study area was carried out using image classification techniques through the application of statistically based decision rule for the determination of the land use/cover type for each pixel in the image. A composite image of Landsat 7 data using band 345 which covers the study area was used. Based on the prior knowledge of the study area and addition research from previous studies, a classification scheme was developed using supervised classification (Fig. 9). Land use is one of the factors that influence groundwater accumulation of the area, the effect of which can increase either infiltration or runoff.
In the study area, the land use/cover types are waterbody, built-up area, vegetation and rock outcrop. Land use provides important indications of the extent of groundwater requirement and utilization. The area with waterbodies is good for groundwater recharge and fallow land is poor for it (Chowdhury et al. 2009). Areas with vegetation will permit proper infiltration of water into the subsurface reducing runoff, while the bare surface will encourage runoff. This is because the surface and pore spaces between the soils are compacted, thus increasing the surface runoff.

The vegetation is the dominant features which covers an area of about $924.9 \mathrm{~km}^{2}$ representing about $65.7 \%$ followed by rock outcrops with an area of about $233.7 \mathrm{~km}^{2}$ representing $16.6 \%$. Water body covers about $192.8 \mathrm{~km}^{2}$ which is about $13.64 \%$, and built-up area covers $56.9 \mathrm{~km}^{2}$ representing $4.04 \%$ of the total land use. The distribution of land use usually enhances groundwater recharge depending on the underlying soil and geologic conditions. An increase in settlement has a negative effect on 


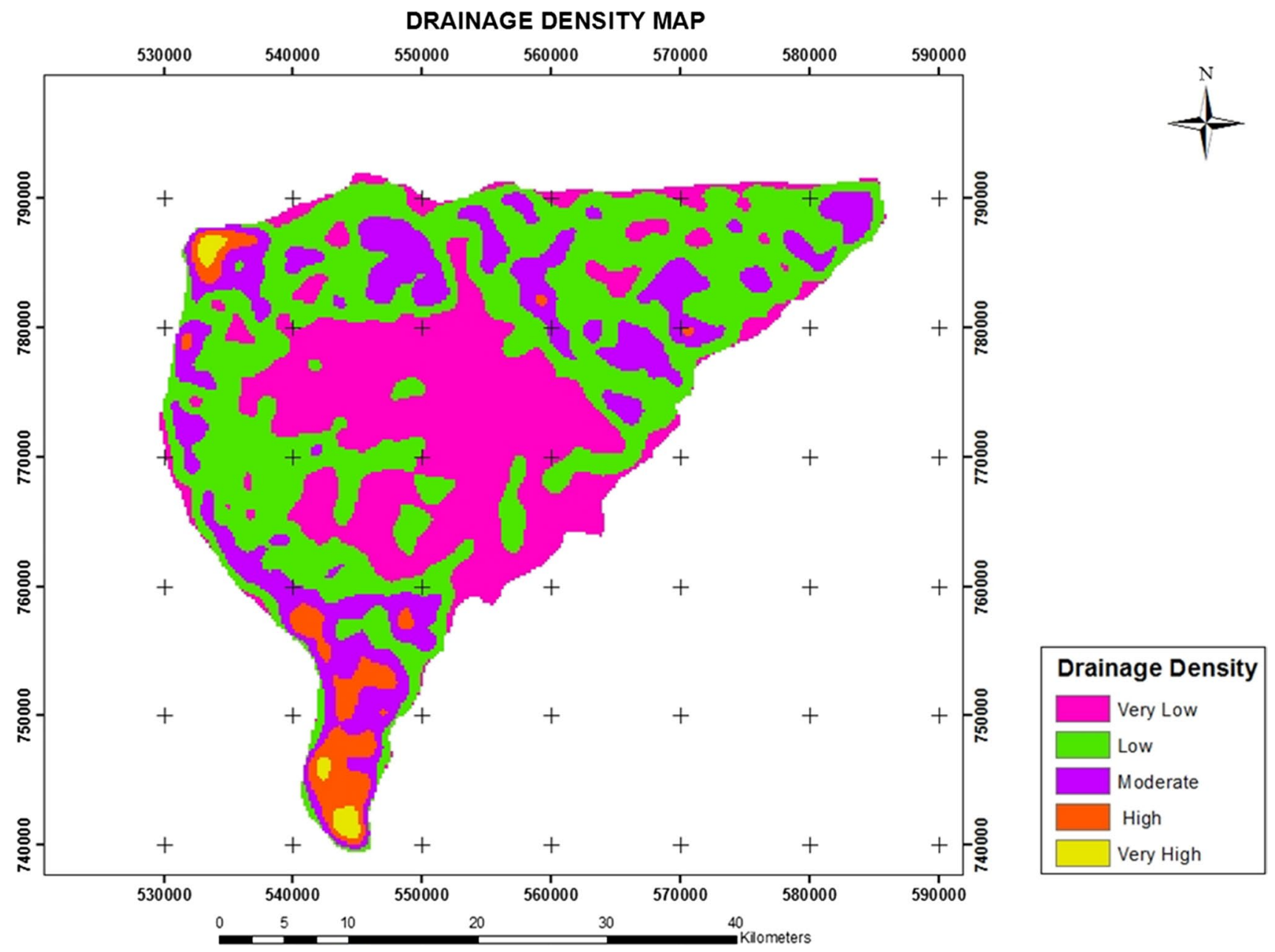

Fig. 11 Drainage density of the study area

groundwater accumulation because it completely closes off the subsurface, preventing any form of infiltration.

\section{Drainage density}

Drainage can simply be described as a way of removing water from both surface and subsurface of an area, while the ratio of the total length of the stream to the area of the drainage basin is known as the drainage density. The drainage map of the area was extracted using hydrology tools of ArcGIS and ASTER DEM as the input data. Dendritic drainage systems are prominent in the study area (Fig. 10). The drainage density map was also generated using ArcGIS spatial analyst extension.

High drainage density is an unfavorable site for groundwater existence, moderate drainage density has moderate groundwater potential, and less/no drainage density is high groundwater potential zone (Todd and Mays 2005). High drainage density was observed at the northeastern, northwestern and southern part of the study area. Hence, there
Table 2 Classification of drainage density in the study area

\begin{tabular}{llll}
\hline $\begin{array}{l}\text { Drainage density } \\
\text { classification }\end{array}$ & $\begin{array}{l}\text { Drainage den- } \\
\text { sity }\left(\mathrm{km} / \mathrm{km}^{2}\right)\end{array}$ & $\begin{array}{l}\text { Area cov- } \\
\text { ered }\left(\mathrm{km}^{2}\right)\end{array}$ & Percentage (\%) \\
\hline Very low & $0-0.81$ & 454.03 & 32.25 \\
Low & $0.81-1.62$ & 626.21 & 44.48 \\
Moderate & $1.62-2.43$ & 264.40 & 18.78 \\
High & $2.43-3.24$ & 45.48 & 3.87 \\
Very high & $3.24-4.05$ & 9.15 & 0.65 \\
\hline
\end{tabular}

will be high occurrence of surface runoff in these parts of the area. Figure 11 is the drainage density thematic map of the study area which shows the subdivision of drainage density in the entire area ranging from very low to very high drainage density and is listed in Table 2 . 


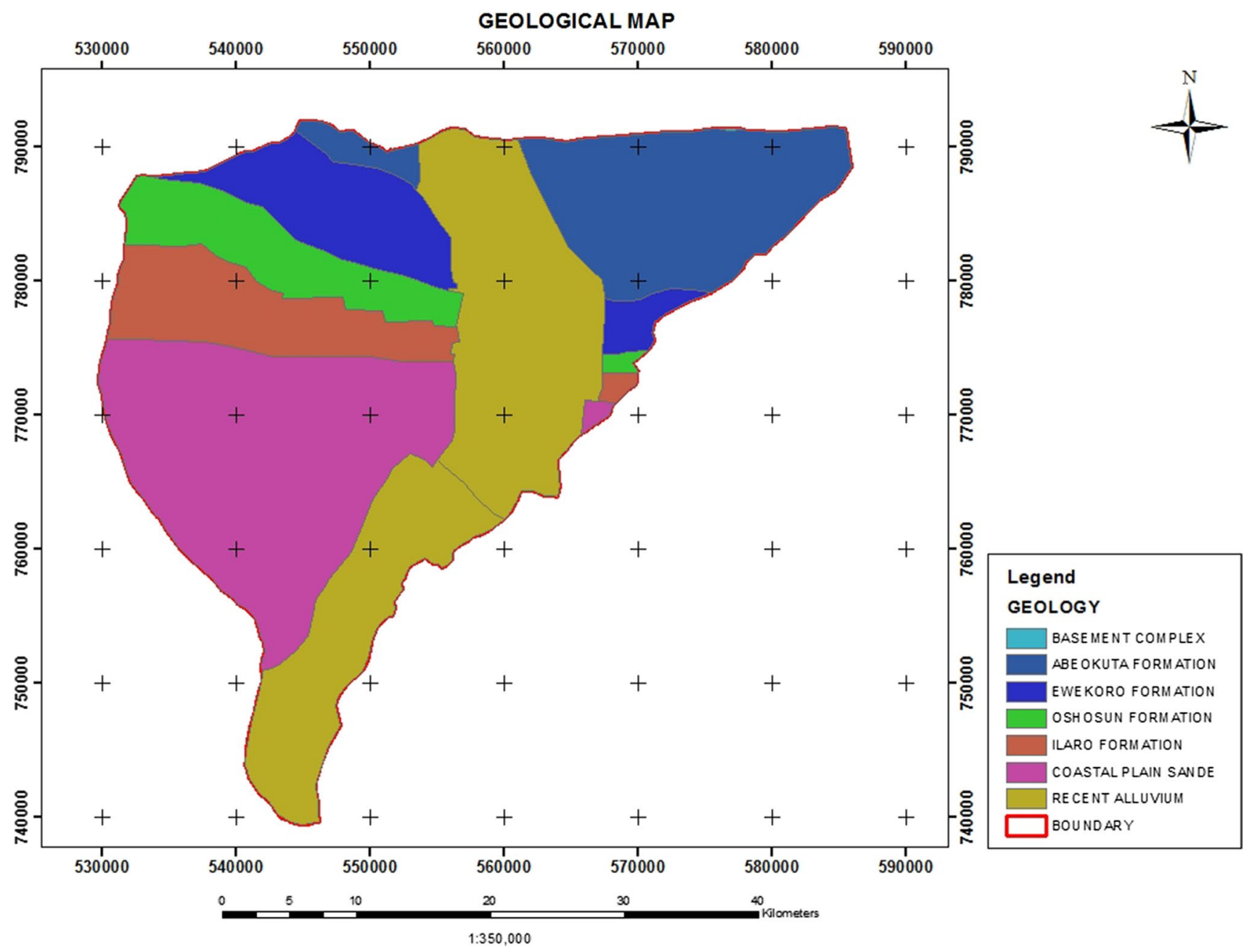

Fig. 12 Geological map of the study area showing geological units in Obafemi Owode LGA (modified after Agagu 1985)

\section{Geology}

The study area is underlain by Abeokuta group which is believed to be the oldest formation constituting the oldest sedimentary unit and lying unconformably on the basement complex. Some rock outcrops were identified at the northcentral part of the study area. The geological units and its composition identified within the study area are:

a. Recent alluvium which consists of loose sand;

b. Coastal plain sands that are made up of soft, very poorly sorted clayey sands and rare thin lignite;

c. Ilaro formation consisting of sandstone;

d. Oshosun formation which consists of shale;

e. Akinbo formation which comprises clay and marl;

f. Ewekoro formation made up of limestone body and highly fossiliferous; and

g. Abeokuta formation which consists of mainly sandstone and conglomerate.
The various geological units identified were reclassified based on their physical properties and relative contribution to groundwater potential (Fig. 12).

\section{Soil Zones}

Soil is described as the product of the interactions of minerals, organic matter, water and air (Juma 1999). Three major soil types were identified in the study area which are loam, loamy clay and sandy soil (Fashae et al. 2013). For coarsegrained soil materials, water infiltrates easily into the subsurface media because of high permeability, while fine-grained soils limit infiltration due to apparently low permeability.

Generally, loam soil shows low permeability, while sandy soil exhibits high permeability as a result of loose particles and irregular grain shape and size. Based on the characteristics of each soil type identified and its effective contribution to groundwater formation, DRASTIC ratings were assigned 


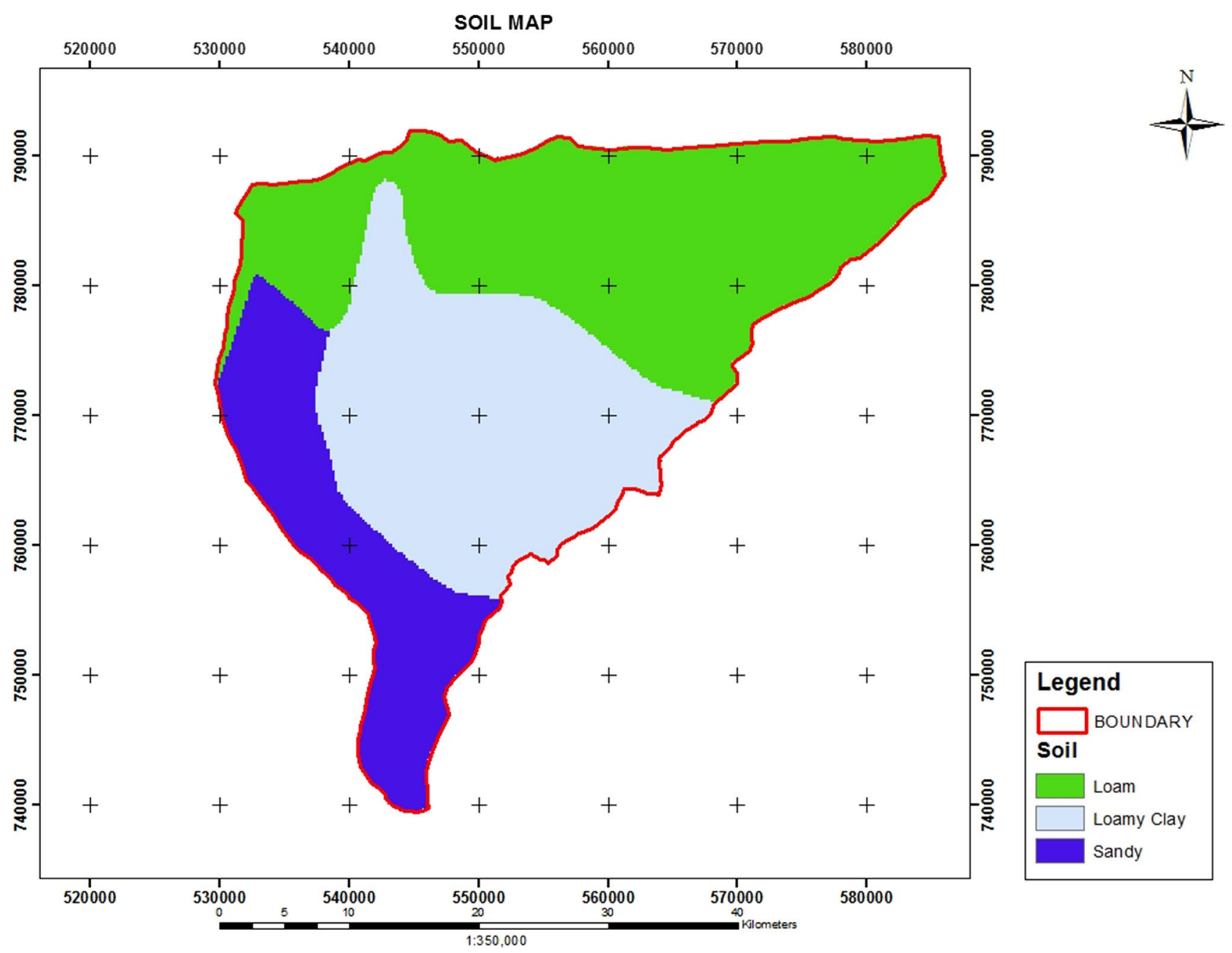

Fig. 13 Soil map of the study area. The soil types within the study area are loam, loamy clay and sandy

to each class; hence, a reclassified soil map was produced (Fig. 13; Table 3).

Based on the hydrological parameters considered and weighted in this study, a groundwater potential map was produced (Fig. 14). This shows five major classes which are very low, low, moderate, high and very high. The map shows the area ranging from the highest potential to the least potential area. In the study area, most areas have very good groundwater potential, while few areas have very poor potential.

\section{Classification of groundwater potential zones}

The groundwater potential zones of Obafemi Owode LGA revealed five distinct zones, namely very low, low, moderate, high and very high zones, whose distribution and extents are $95.73 \mathrm{~km}^{2}(6.8 \%), 298.46 \mathrm{~km}^{2}$ $(21.2 \%), 481.76 \mathrm{~km}^{2}(34.22 \%), 334.64 \mathrm{~km}^{2}(23.77 \%)$ and $196.39 \mathrm{~km}^{2}(13.95 \%)$, respectively, and are presented in
Table 4. The prospective map, as presented in Fig. 14, gives a swift evaluation of the occurrence of groundwater resources in the study area.

The groundwater potential map shows that the upper northwestern, the southern and limited region at the central parts of the study area generally have very low to low potentials covering an area of about $28 \%$, while the other parts generally show high potential depicting about $71 \%$ of the area. The generally moderate to very high groundwater potential of the study area as shown by over $71 \%$ coverage is a confirmation of good capability as aquifers of sedimentary terrain. Moreover, a closer assessment of the groundwater potential map shows that the distribution reflects the patterns of soil in addition to the geological control. High drainage density as well as high and low percentages of slope which can enhance infiltration of water into the groundwater system could be attributed to the observed high potential of groundwater exhibited in the southern parts of the study area. 
Table 3 Parameters description, DRASTIC ratings and weighting

\begin{tabular}{|c|c|c|c|c|c|}
\hline Parameter & Attributes & Range & Rating & Description & Weight \\
\hline Geology & $\begin{array}{l}\text { Abeokuta } \\
\text { Ewekoro } \\
\text { Ilaro formation } \\
\text { Recent Alluvium } \\
\text { Coastal Plain } \\
\text { Oshosun }\end{array}$ & & $\begin{array}{l}10 \\
8 \\
7 \\
6 \\
4 \\
2\end{array}$ & $\begin{array}{l}\text { Consolidated and unconsolidated medium which acts as an } \\
\text { aquifer based on the grain size, shape and fractures }\end{array}$ & 6 \\
\hline Soil & $\begin{array}{l}\text { Loam } \\
\text { Loamy clay } \\
\text { Sandy }\end{array}$ & & $\begin{array}{l}5 \\
2 \\
7\end{array}$ & $\begin{array}{l}\text { Weathered materials of the uppermost portion of the vadose } \\
\text { zone characterized by significant biological activities }\end{array}$ & 5 \\
\hline Land use & $\begin{array}{l}\text { Vegetation } \\
\text { Waterbody } \\
\text { Outcrop } \\
\text { Built-up }\end{array}$ & & $\begin{array}{l}10 \\
5 \\
3 \\
1\end{array}$ & Describes various activities going on in a particular area & 4 \\
\hline Slope & $\begin{array}{l}\text { Flat } \\
\text { Gentle } \\
\text { Moderate } \\
\text { Steep } \\
\text { Very steep }\end{array}$ & & $\begin{array}{l}10 \\
9 \\
7 \\
4 \\
2\end{array}$ & Steepness of the landform & 3 \\
\hline Lineament density & $\begin{array}{l}\text { High } \\
\text { Moderate } \\
\text { Medium } \\
\text { Poor } \\
\text { Very poor }\end{array}$ & $\begin{array}{l}1.16-1.45 \\
0.87-1.16 \\
0.58-0.87 \\
0.29-0.58 \\
0-0.29\end{array}$ & $\begin{array}{l}10 \\
7 \\
5 \\
3 \\
1\end{array}$ & Line features representing cracks & 2 \\
\hline Drainage Density & $\begin{array}{l}\text { Low drainage } \\
\text { Moderate } \\
\text { High drainage }\end{array}$ & & $\begin{array}{l}10 \\
7 \\
2\end{array}$ & Total length of the stream to the area of the drainage basin & 1 \\
\hline
\end{tabular}

To verify the groundwater potential zones delineated by GIS and remote sensing methodology, data from five boreholes were collected from two localities: Ijapo (northwestern part) and Laloko (central portion) around the study area. The wells generally range between 60 and $120 \mathrm{~m}$. Investigation shows that four of the boreholes (Ijapo 1, 2, 3 and Laloko 1) usually experience low volume of water when a lot of water is drawn from them. Ijapo 1, 2 and 3 wells experience complete dryness during dry season, while Laloko 2 well with a depth of about $13 \mathrm{~m}$ produces all-round the year but diminishes during the dry season.

Eight areas were delineated for future groundwater development based on the size of the communities and the population. They are labeled as A, B, C, D, E, F, G and H in Fig. 15. Electrical resistivity method was proposed for further study in the identified areas. 2D resistivity survey was later conducted within area "D" in the southeastern part of the study area. This is because area "D" has high groundwater potential as shown in Fig. 15.

\section{D Resistivity Survey of Area “D”}

The geophysical mapping of area "D" was undertaken. A total of 4.8 line-kilometers of 2D resistivity profiles were collected (Fig. 16). The result of the processed 2D resistivity data sets is presented as $2 \mathrm{D}$ inverted resistivity sections
(Figs. 17, 18, 19, 20, 21). The 2D section is a color-coded format, and the resistivity of each color is presented in a logarithmic color scale bar on the sections. The vertical scale on the section is the depth investigated (in meters), while the horizontal scale is the distance covered (on ground, also in meters) as described on the map. The interpretation of the $2 \mathrm{D}$ section is based on the regional and local geology of the study area. Meanwhile, subsurface lithology associated with resistivity range is guided with existing resistivity charts having considered other local factors that may result in deviation of resistivity values.

\section{Traverse 1 to 5}

The $2 \mathrm{D}$ inverted resistivity section using the dipole-dipole and pole-dipole arrays on traverse 1 to 5 has shown the vertical and lateral distribution of subsurface resistivity as presented in Figs. 17, 18, 19, 20 and 21. The 2D sections have delineated three to five geoelectric layers based on the spread and array configurations. The geoelectric layers are response from the variation of resistivity signatures within the major lithologies in the study area.

The first geoelectric layer (Figs. 17, 18, 19, 20 and 21) is interpreted as topsoil (composed of clay and sand) and lateritic materials having electrical resistivity ranging from 14.2 to $5623 \Omega \mathrm{m}$ with thicknesses between 7 and $33 \mathrm{~m}$. 


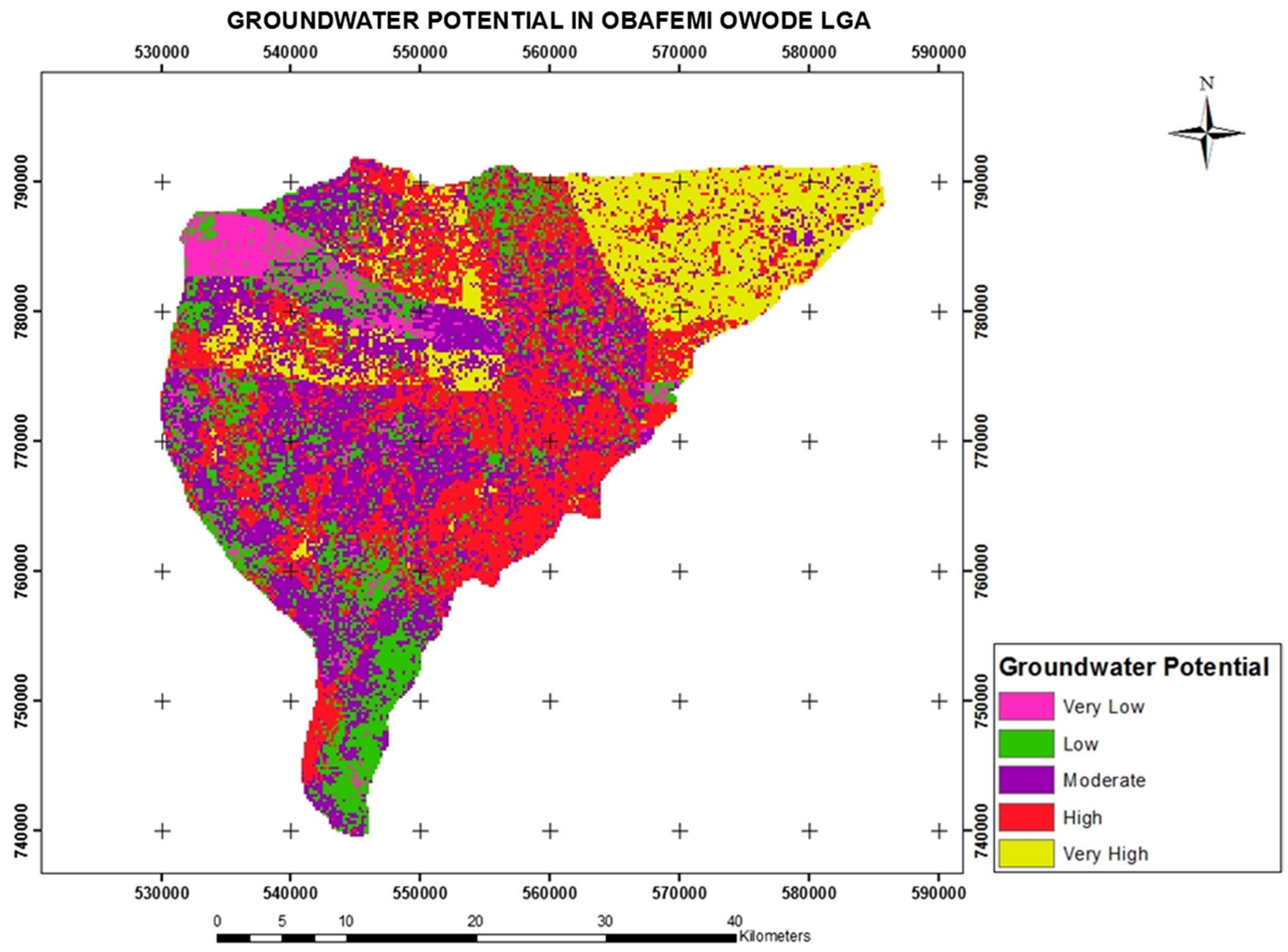

Fig. 14 Prospective groundwater zones of the study area

Table 4 Classification of groundwater potential zones

\begin{tabular}{lcc}
\hline Class & Area covered $\left(\mathrm{km}^{2}\right)$ & Percentage \\
\hline Very low & 95.73 & 6.8 \\
Low & 298.46 & 21.2 \\
Moderate & 481.76 & 34.22 \\
High & 334.64 & 23.77 \\
Very high & 196.39 & 13.95 \\
\hline
\end{tabular}

The second geoelectric layer is composed of relatively low electrical resistivity ranging from 1 to $21.7 \Omega \mathrm{m}$ and depth range of 30 to $65 \mathrm{~m}$ (Figs. 17, 18, 19, 20 and 21). The second geoelectric layer was interpreted as shale/clay. The third geoelectric layer is represented by electrical resistivity ranging from 36 to $1106 \Omega \mathrm{m}$ (Fig. 17a, b). This geoelectric layer is interpreted as limestone. The low electrical resistivity values suggest fractured limestone filled with water or limestone being marly. Limestone is a major aquifer within the study area and can be exploited for groundwater development. The aquifer within the limestone region may have some degree of hardness due to dissolved minerals (calcium and possibly magnesium) which may limit the domestic use. While the dipole-dipole has provided higher resolution of nearsubsurface region in the study area, the pole-dipole array due to its higher depth of penetration has delineated deeper subsurface region which constitutes the fourth and fifth geoelectric layers.

The electrical resistivity of the fourth geoelectric layer ranges from 35 to $59.4 \Omega \mathrm{m}$ with depth ranging from 125 to $170 \mathrm{~m}$ (Figs. 17b and 19b). The fourth geoelectric layer is interpreted as sand/calcareous sandstone or clayey sand. The low electrical resistivity exhibited by the sand can be associated with being calcareous (by the overlying limestone), and the aquifer within this depth may exhibit some degree of hardness.

The fifth geoelectric layer (Figs. 17b and 19b) delineated with electrical resistivity range of about 100 to $130 \Omega \mathrm{m}$ which indicates sand/sandstone layer. The fifth layer constitutes a major aquifer with freshwater and is delineated to an 


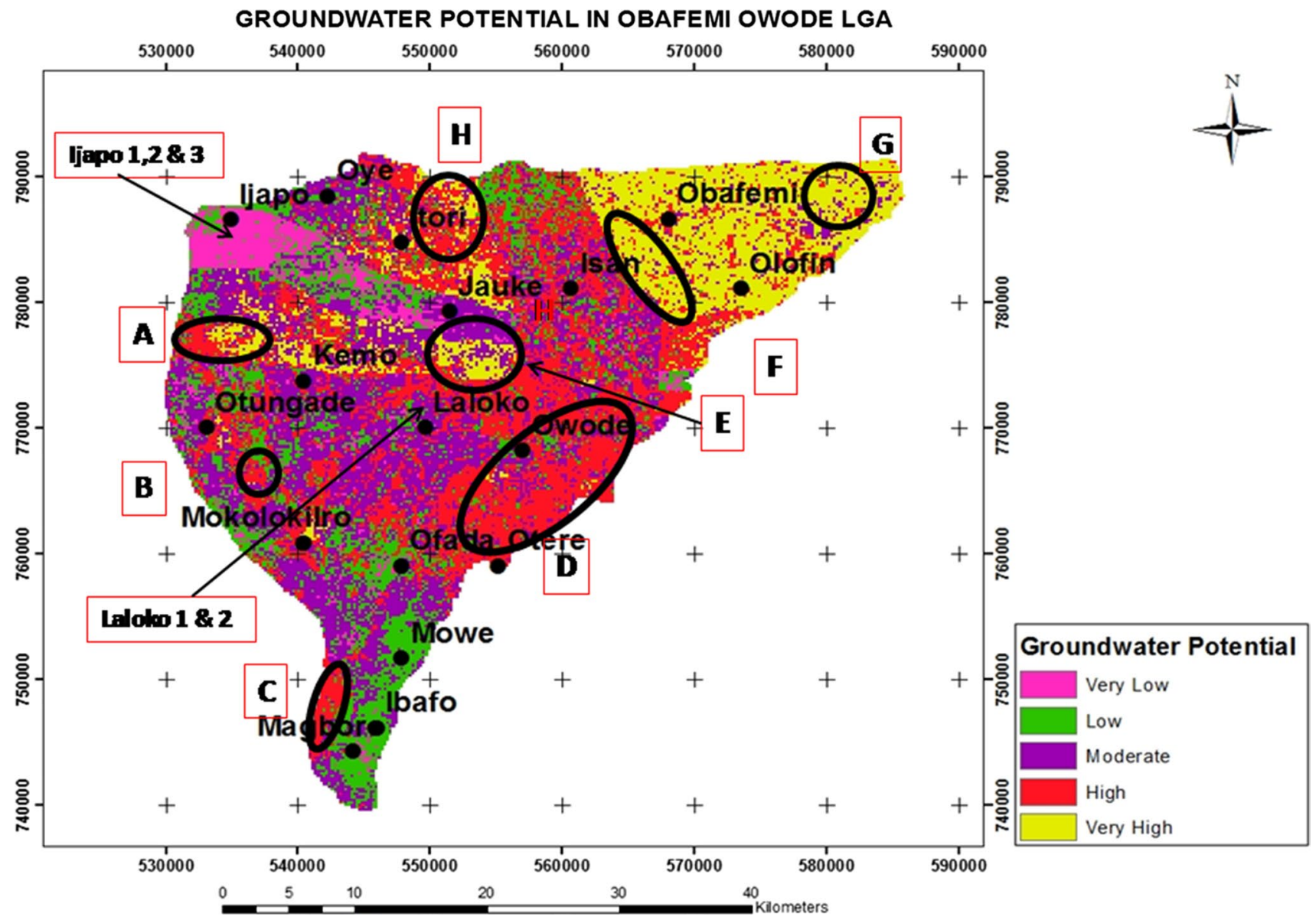

Fig. 15 Prospective groundwater zones of the study area showing the area delineated for resistivity survey. Area "D" was targeted for 2D resistivity survey

average depth of about $198 \mathrm{~m}$. The aquifer within the sand/ sandstone can be exploited for groundwater development, especially for both domestic and industrial use. Pole-dipole resistivity profile of traverse 5 was excluded in this interpretation because the quality is very poor. This was because the electrode at infinity was fiddled with while the reading was ongoing.

\section{Ground truth of Area “D”}

The study area consists of both carbonate and silicate aquifers which are limestone and sandstone, respectively. This conform to the regional geology of Dahomey basin which is mainly an intercalation of sand, sandstone, silt, shale and limestone. The resistivity response shows the presence of limestone and sandstone as aquifers within the subsurface. The resistivity profiles delineated three major aquifers within the survey area based on the inference from resistivity values, previous knowledge and regional geology of the area; the region between shot point 120 to 250 on profile one (traverse 1) was recommended for citing a borehole for groundwater development in the study area (Table 5). The depth of 72-200 $\mathrm{m}$ with tolerance of $2 \mathrm{~m}$ was recommended for groundwater development through borehole drilling. The aim is to tap into one of the underlie aquifers $2,3,4,5$ or 6 , which could be silicate or carbonate depending on the budget (depth).

Figure 22 is the lithology log of borehole \#1 drilled to a depth of $88 \mathrm{~m}$ at electrode 133 on traverse 1. It targeted "aquifer 4" at a depth of about $75 \mathrm{~m}$ with a yield of $7.1 \mathrm{~m}^{2} /$ hour. Integrating the lithology log with $2 \mathrm{D}$ resistivity data, there is a good correlation between the resistivity profiles and the drilled well (Fig. 23). 


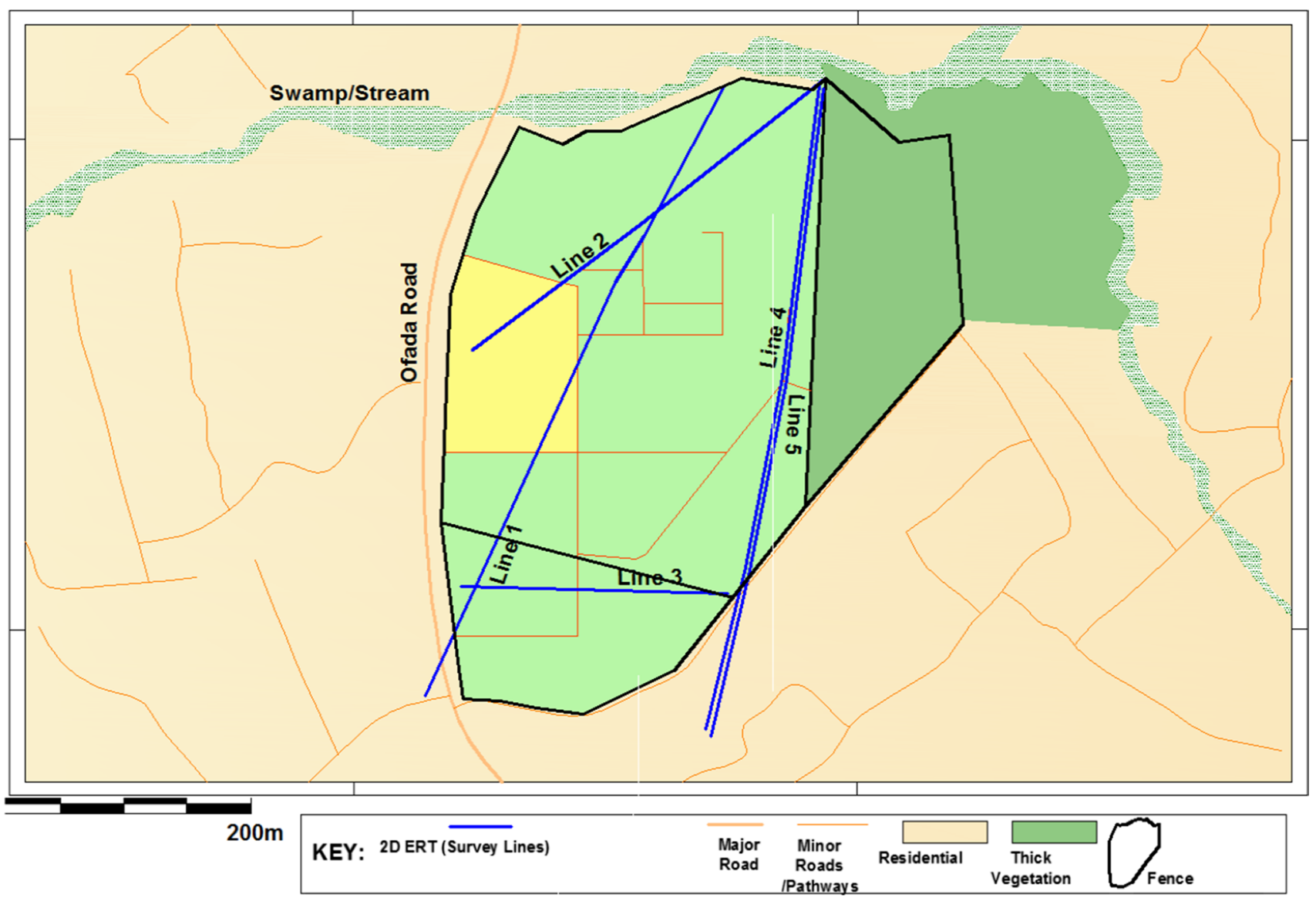

Fig. 16 Basemap of the study within area "D" showing the traverse lines and other features such as vegetation and major roads
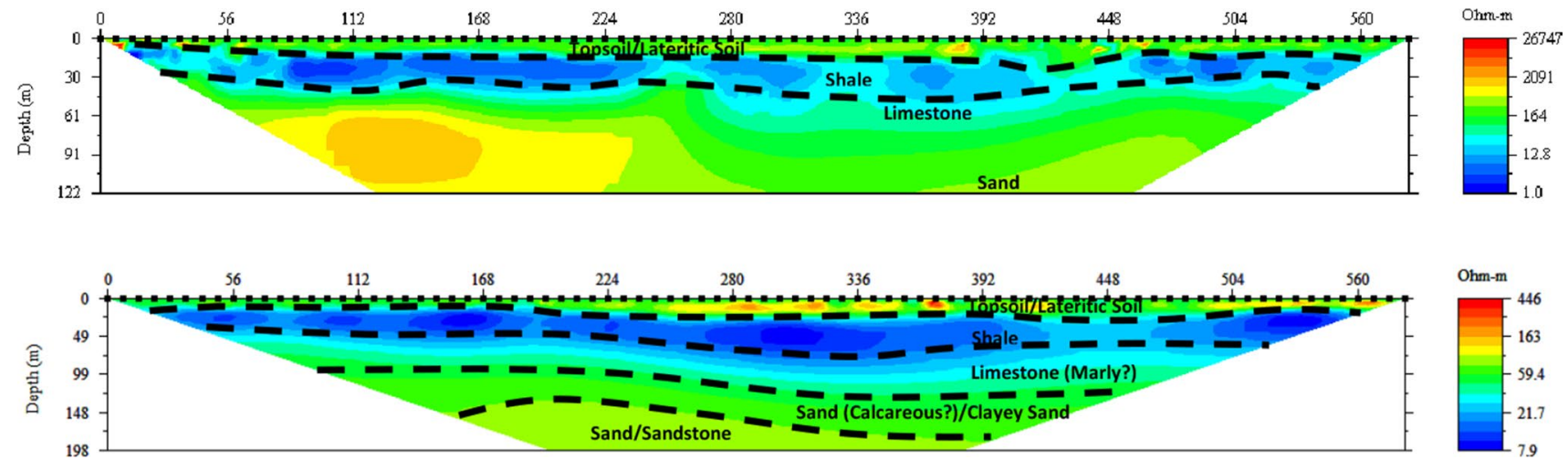

Fig. 17 a 2D inverted resistivity section with dipole-dipole array on traverse 1 . b $2 \mathrm{D}$ inverted resistivity section with pole-dipole array on traverse 1

\section{Conclusions}

In this study, an integrated approach using GIS, remote sensing and $2 \mathrm{D}$ electrical resistivity methods was adopted to locate potential sites for groundwater development in both carbonate and clastic aquifers in Obafemi Owode area,
Southwestern Nigeria. GIS and remote sensing were adopted as reconnaissance survey techniques in this study. This is to reduce the cost and time taken using other methods of groundwater exploration when conducting exploration on a regional scale. It involves a weighted overlay model using six different effective weighted parameters, including geology, lineament density, slope, soil, land use and drainage 

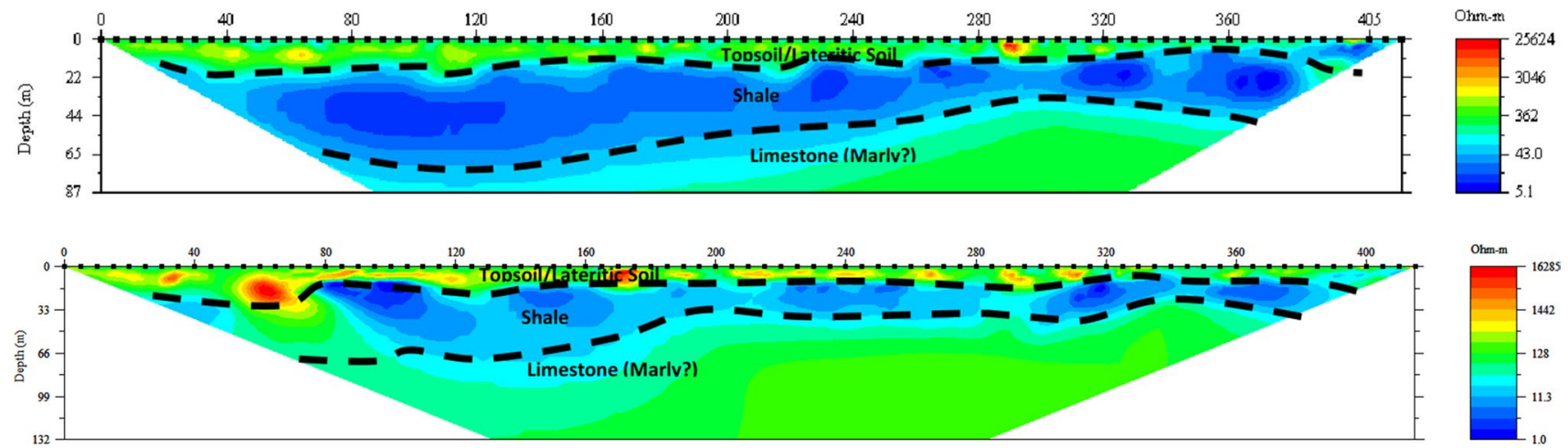

Fig. 18 a 2D inverted resistivity section with dipole-dipole array on traverse 2. b 2D inverted resistivity section with pole-dipole array on traverse 2

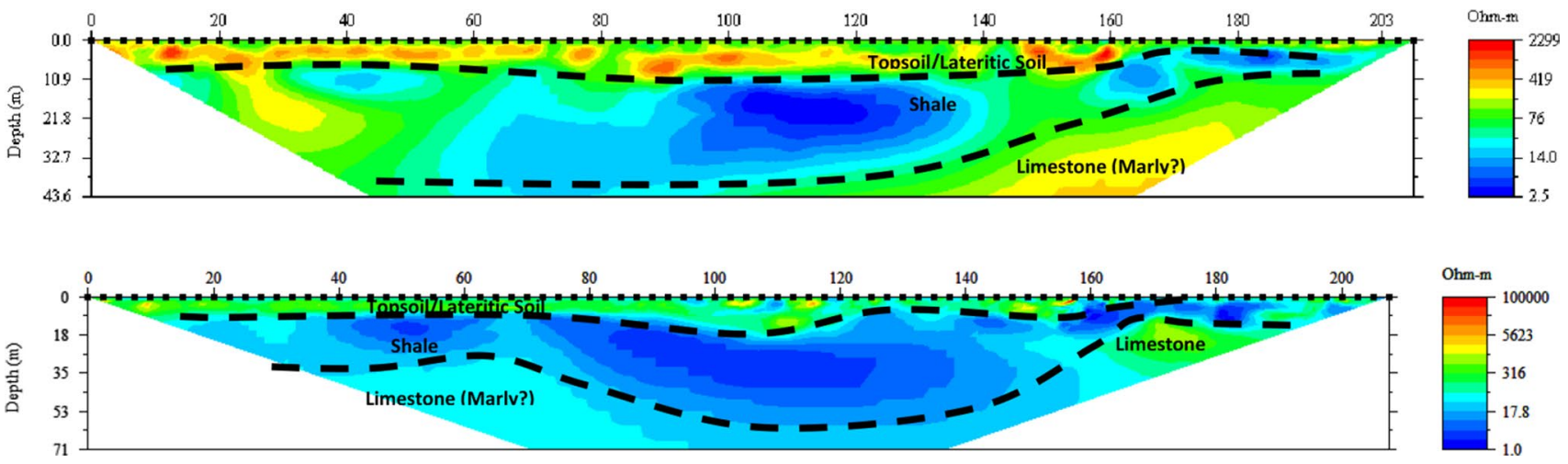

Fig. 19 a 2D inverted resistivity section with dipole-dipole array on traverse 3. b 2D inverted resistivity section with pole-dipole array on traverse 3
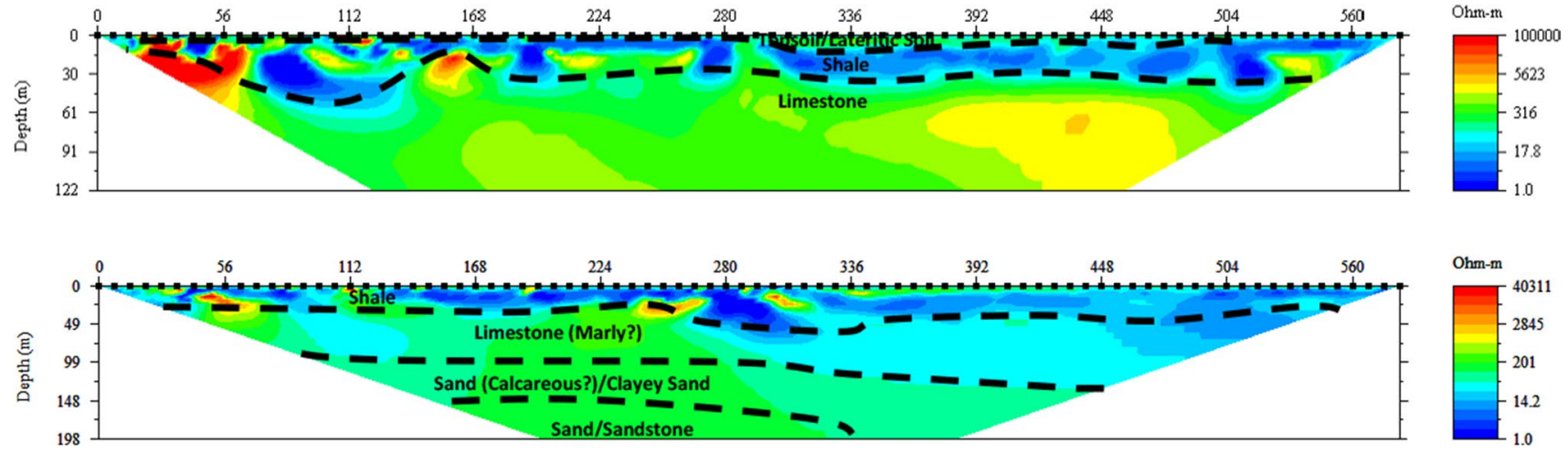

Fig. 20 a 2D inverted resistivity section with dipole-dipole array on traverse 4. b 2D inverted resistivity section with pole-dipole array on traverse 4

density. The overlay scheme focuses on the factors that influence groundwater occurrence which are dependent on surface characterization. All the thematic layers were subjected to image processing; the data integration was carried out in ENVI 5.0 and ArcGIS 10.2 environment for decision making. The groundwater potential map was obtained by algebraic summation of these effective parameters being multiplied by their effective weights. Five major classes of groundwater potential were delineated in the area based on hydrological parameters considered. The groundwater 


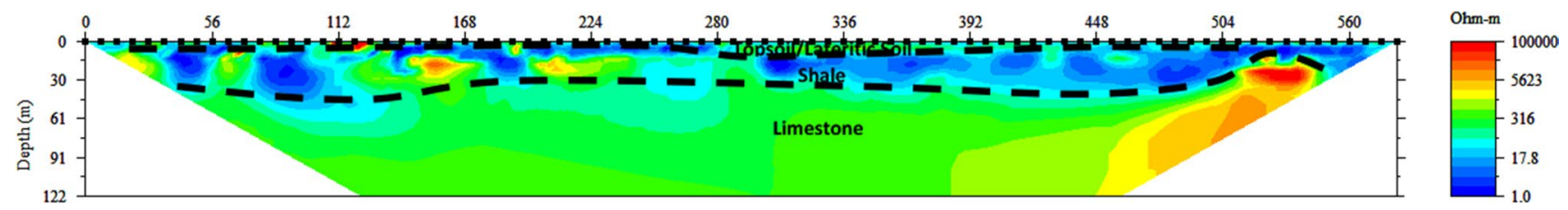

Fig. $212 \mathrm{D}$ inverted resistivity section with dipole-dipole array on traverse 5

Table 5 Interpreted electrical resistivity profile of traverse 1

\begin{tabular}{|c|c|c|c|c|c|c|}
\hline \multirow[t]{2}{*}{ Inferred lithology } & \multicolumn{2}{|l|}{ Electrode 131} & \multicolumn{2}{|l|}{ Electrode 280} & \multicolumn{2}{|l|}{ Electrode 392} \\
\hline & Pole-dipole (m) & Dipole-dipole (m) & Pole-dipole (m) & Dipole-dipole (m) & Pole-dipole (m) & Dipole-dipole (m) \\
\hline Top soil/laterite & $0-10.5$ & $0-14$ & $0-24$ & $0-15$ & $0-23$ & $0-17$ \\
\hline Shale & $10-543$ & $14-36$ & $24-67.4$ & $15-51$ & $23-63$ & $17-45$ \\
\hline Limestone & $43-75$ & $36-59$ & $67.4-111.3$ & $51-136$ & $63-125$ & $45-123$ \\
\hline Sand/clay sand & $75-150$ (projected) & $59-122$ & $111.3-154.1$ & $136-122$ & $125-178.5$ & $123-122$ \\
\hline Sand/sandstone & $? ?$ & & $154.1-198$ & & $178.5-198$ & \\
\hline
\end{tabular}

?? The depth range of sandstone could not be ascertained

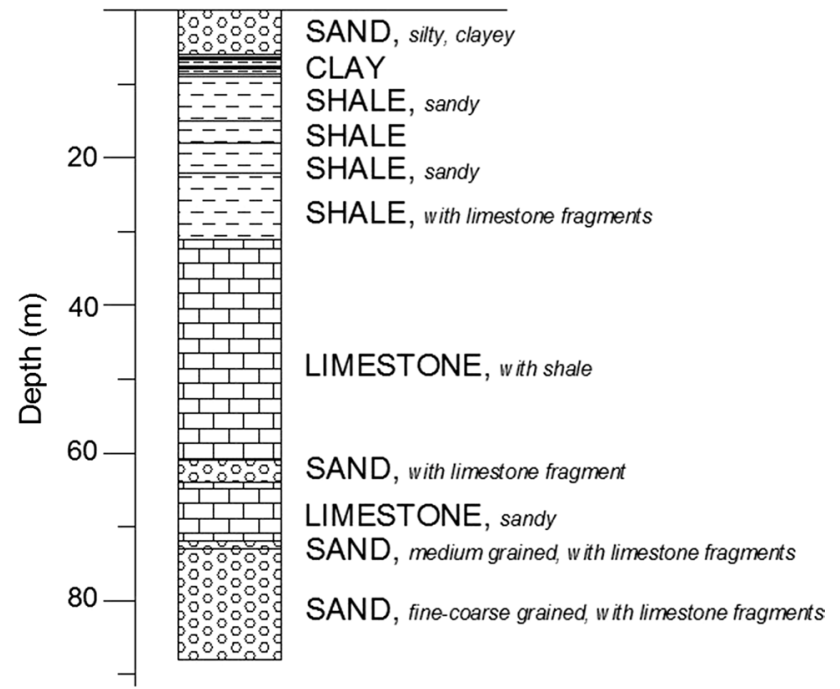

Fig. 22 Lithologic $\log$ of borehole 1. The well was drilled to a depth of about $88 \mathrm{~m}$ at electrode 133 on traverse 1

potential map generated shows that the upper northwestern, the southern and limited region at the central parts of the study area generally have very low to low potentials with area coverage of about $28 \%$, while the other portion generally exhibits high potentials representing about $71 \%$ of the study area. Hence, the groundwater potential model shows that $71 \%$ of Obafemi Owode LGA was classified as high potential areas for groundwater exploration. Data from five existing shallow hand dug wells were collected from two communities, namely Ijapo area (classified as "very low" groundwater potential zone) and Laloko area (which is classified as "moderate" groundwater zone produces all-round the year but exhibits lower groundwater production in the dry season). The $2 \mathrm{D}$ inverted resistivity sections using the dipole-dipole and pole-dipole arrays were used to verify the "high" groundwater potential zone delineated using GIS and remote sensing. This was carried out on five traverses (1 to 5). The results of 2D resistivity delineated three to five geoelectric layers based on the spread and array configurations. The geoelectric layers are response from the variation of resistivity signatures within the major lithologies in the study area. Dipole-dipole configuration delineated three layers which are topsoil (14.2 to $5623 \Omega \mathrm{m}$ ), shale/ clay ( 1 to $21.7 \Omega \mathrm{m}$ ) and limestone (36 to $1106 \Omega \mathrm{m}$ ). However, pole-dipole array delineated deeper region which is 


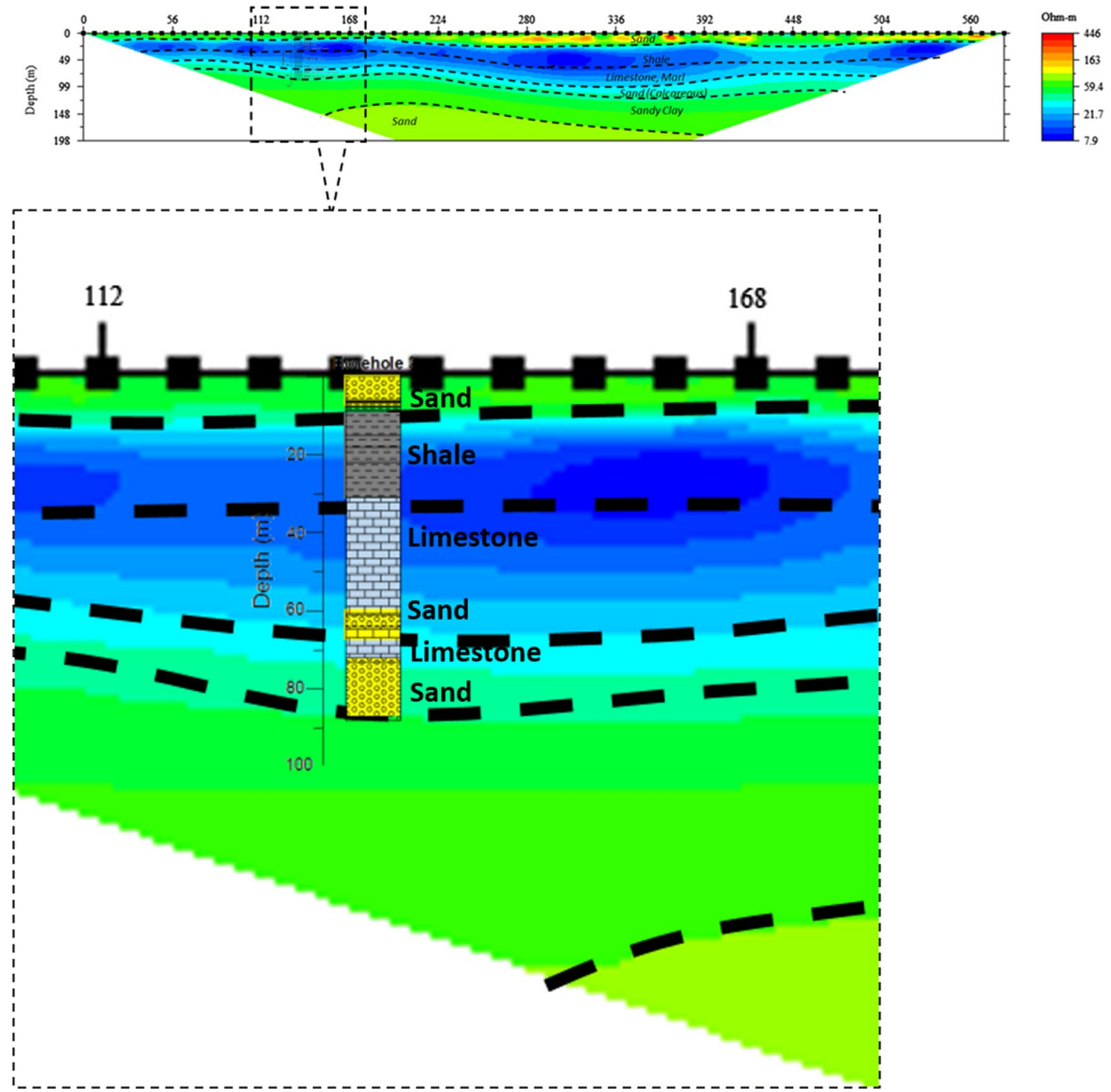

Fig. 23 Interpreted 2D inverted resistivity profile of line 1 correlated with borehole \#1

interpreted as sand/calcareous/clayey sand/sandstone (35 to $59.4 \Omega \mathrm{m}$ ) and sand/sandstone (100 to $130 \Omega \mathrm{m}$ ).

There is a good correlation between the $2 \mathrm{D}$ resistivity profile and the borehole \#1 drilled to a depth of $75 \mathrm{~m}$ on traverse 1 with a yield of $7.1 \mathrm{~m}^{2} /$ hour. The results from this study have shown that the high potential zones would play a key role in future expansion of drinking water and irrigation development in the study area.

Funding This research did not receive any specific grant from funding agencies in the public, commercial or not-for-profit sectors.

\section{Compliance with ethical standards}

Conflict of interest The authors declare that there is no conflict of interest regarding the publication of this article.

Open Access This article is licensed under a Creative Commons Attribution 4.0 International License, which permits use, sharing, adaptation, distribution and reproduction in any medium or format, as long as you give appropriate credit to the original author(s) and the source, provide a link to the Creative Commons licence, and indicate if changes were made. The images or other third party material in this article are included in the article's Creative Commons licence, unless indicated otherwise in a credit line to the material. If material is not included in the article's Creative Commons licence and your intended use is not permitted by statutory regulation or exceeds the permitted use, you will need to obtain permission directly from the copyright holder. To view a copy of this licence, visit http://creativecommons.org/licenses/by/4.0/. 


\section{References}

Abdullahi N, Iheakanwa A (2013) Groundwater detection in basement complex of Northwestern Nigeria using 2D electrical resistivity and offset wenner techniques. Int J Adv Technol Eng Res 2(7):529-535

Acharya T, Kumbhakar S, Prasad R, Mondal S, Biswas A (2019) Delineation of potential groundwater recharge zones in the coastal area of north-eastern India using geoinformatics. Sustain Water Resour Manag 5:533-540. https://doi.org/10.1007/ s40899-017-0206-4

Adegoke OS (1969) The Eocene stratigraphy of southern Nigeria: bull. Bur Econ Geol Miner Mem 6:23-28

Agagu OK (1985) A geological guide to bituminous sediments in Southwestern Nigeria: Report, Department of Geology, University of Ibadan

AGI (2009) Instruction manual for earth imager 2D version 2.4.0. Advanced Geosciences, Inc., Austin, TX

Aizebeokhai AP, Oyeyemi KD (2017) Geoelectrical characterization of basement aquifers: the case of Iberekodo, southwestern Nigeria. Hydrogeol J 26(2):651-664. https://doi.org/10.1007/s1004 0-017-1679-9

Al-Bakri JT, Al-Jahmany YY (2013) Application of GIS and remote rensing to groundwater exploration in Al-Wala basin in Jordan. $\mathrm{J}$ Water Resour Prot 5:962-971

Aller L, Bennett T, Lehr JH, Petty RJ, Hackett G (1987) DRASTIC: a standardized system for evaluating ground water pollution potential using hydrogeologic settings. In: Robert S (ed) Kerr Environmental Research Laboratory, U. S. Environmental Protection Agency, p 455

Archie GE (1942) The electrical resistivity log as an aid in determining some reservoir characteristics. Trans Am Inst Miner Metall Pet Eng 146:54-62

Avbovbo AA (1978) Tertiary lithostratigraphy of Niger Delta. Am Assoc Pet Geol Bull 62(2):295-300

Billman HG (1976) Offshore stratigraphy and paleontology of the Dahomey embayment. In: Proceedings, 7th African micropaleontology colloquium, lle-Ife

Burke KC, Dewey JF (1972) Orogeny in Africa. In: Dessauvagie TFJ, Whiteman AJ (eds) Africa geology. University of Ibadan Press, Ibadan, pp 583-608

Chowdhury A, Jha M, Chowdary V, Mal B (2009) Integrated remote sensing and GIS-based approach for assessing groundwater potential in West Medinipur district. Int J Remote Sens 30:231-250

De Klasz I (1977) The west African sedimentary basins. In: Moullade M, Nairn AEM (eds) The phanerozoic geology of the world. The Mesozoic, vol 1. Elsevier, Amsterdam, pp 371-399

Dee N, Baker J, Drobny N, Duke K, Whitman I, Fahringer D (1973) An environmental evaluation system for water resource planning. Water Resour Res 9(3):523-535

Elbeih SF (2015) An overview of integrated remote sensing and GIS for groundwater mapping in Egypt. Ain Shams Eng J 6(1):1-15

Fashae OA, Tijani MN, Talabi AO, Adedeji OI (2013) Delineation of groundwater potential zones in the crystalline basement terrain of SW-Nigeria: an integrated GIS and remote sensing approach. Water Sci 4:19-38

Federal Office of Statistics (FOS) Annual Report 2019. Federal Office of Statistics, Abuja

Fenta CW (2015) Spatial analysis of groundwater potential using remote sensing and GIS-based multi-criteria evaluation in Raya Valley, northern Ethiopia. Hydrogeol J 23(1):195-206

Freeze R, Cherry J (1979) Groundwater. Prentice-Hall, New Jersey http://www.esri.com/software/arcgis

http://www.exelisvis.com/ProductsServices/ENVIProducts/ENVI. aspx)
El Hadanai D, Limam N, El Meslouhi R (1993) Remote sensing applications to groundwater resources. In: Proceedings international symposium operationalization of remote sensing. Earth Science Applications, ITC, Enschede, The Netherlands, vol 9, pp 93-103

Herman BM, Langseth MG, Hobart MA (1977) Heat flow in the oceanic crust bounding western Africa. Tectonogeophysics 41:61-77

Hoffman J (2005) The future of satellite remote sensing in hydrogeology. Hydrogeol J 13(1):247-250

Jha M, Chowdhury A, Chowdary V, Peiffer S (2007) Groundwater management and development by integrated remote sensing and GIS: prospect and constraint. Water Resour Manag 21(2):427-467

Jones HA, Hockey RD (1964) The Geology of part of Southwestern Nigeria: Explanation of 1: 250,000 sheets Nos. 59 and 68. Authority of the Federal Government of Nigeria

Juma NG (1999) Introduction to soil science and soil resources. Volume I in the Series "The pedosphere and its dynamics: a systems approach to soil science.” Salman Productions, Sherwood Parkpp, p 335

Kayode J, Adelusi A, Nawawi M, Bawallah M, Olowolafe T (2016) Geo-electrical investigation of near surface conductive structures suitable for groundwater accumulation in a resistive crystalline basement environment: a case study of Isuada, southwestern Nigeria. J Afr Earth Sci 119:289-302

Khairul AM, Juhari MA, Ibrahim A (2000) GIS aided groundwater potential mapping of the Langat Basin. In: Teh GH, Pereira JJ, Ng TF (eds) Proceedings annual geological conference, Geological Society of Malaysia Malaysia. pp 405-410

Khan MA, Moharana PC (2002) Use of remote sensing and GIS in the delineation and characterization of groundwater potential zones. J Indian Soc Remote Sens 30(3):131-141

Kumar VA, Mondal NC, Ahmed S (2020) Identification of groundwater potential zones using RS, GIS and AHP techniques: a case study in a part of Deccan volcanic province (DVP), Maharashtra, India. J Indian Soc Remote Sens 48:497-511. https://doi. org/10.1007/s12524-019-01086-3

Loke MH (1999) Time-lapse resistivity imaging inversion. In: 5th meeting of the environmental and engineering geophysical society European section proceedings

Machiwal D, Jha MK, Mal BC (2011) Assessment of groundwater potential in a semi-arid region of India using remote sensing, GIS and MCDM techniques. Water Resour Manag 25:1359-1386

Mehmood Z, Khan NM, Sadiq S, Mandokhail SJ, Ashiq ZA (2020) Assessment of subsurface lithology, groundwater depth, and quality of UET Lahore, Pakistan, using electrical resistivity method. Arab J Geosci 13:281. https://doi.org/10.1007/s12517-020-5260-9

Mpanda S (1997) Geological Development of East African Coastal Basin of Tanzania, vol 45. Stockholm University, Department of Geology and Geochemistry, Stockholm, p 121

Muchingami I, Chuma C, Gumbo M, Hlatywayo D, Mashingaidze R (2019) Review: approaches to groundwater exploration and resource evaluation in the crystalline basement aquifers of Zimbabwe. Hydrogeol J 27:915-928. https://doi.org/10.1007/s1004 0-019-01924-1

Murthy KSR (2000) Groundwater potential in a semi-arid region of Andhra Pradesh: a geographical information system approach. Int J Remote Sens 21(9):1867-1884

Nag S, Anindita L (2011) Integrated approach using remote sensing and GIS techniques for delineating groundwater potential zones in Dwarakes war watershed, Bankura District. West Bengal Int J Geomatics Geosci 2:430-442

Nwachukwu S, Bello R, Balogun AO (2019) Evaluation of groundwater potentials of Orogun, South-South part of Nigeria using electrical resistivity method. Appl Water Sci 9:184. https://doi. org/10.1007/s13201-019-1072-Z

Ogun State Water Corporation (OG.S.W.C) Investment plan report, May2010

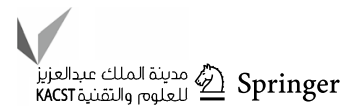


Okosun EA (1990) A review of the Cretaceous stratigraphy of the Dahomey Embayment, West Africa. Cretaceous Res 11:17-27

Olasehinde P (2010) The Groundwater of Nigeria: A solution to sustainable national water needs. Inaugural Lecture Series 17, pp $1-56$

Omatsola ME, Adegoke OS (1981) Tectonic evolution and Cretaceous stratigraphy of the Dahomey Basin. J Mining Geol 18:130-137

Onuoha KM, Ofoegbu CO (1988) Subsidence and thermal history of the Dahomey embayment: implications for petroleum exploration. Niger Assoc Pet Explorationists Bull 3(2):131-142

Oyeyemi KD, Aizebeokhai AP, Olofinnade OM, Sanuade OA (2018) Geoelectrical investigations for groundwater exploration in crystalline basement terrain, SW Nigeria: implications for groundwater resources sustainability. Int J Civil Eng Technol 9(6):765-772

Reyment RA (1965) Aspects of the geology of Nigeria. Ibadan University Press, Ibadan, p 133

Reynolds JM (1997) An introduction to applied and environmental geophysics. Wiley, Chichester

Sander P, Chesley M, Minor T (1996) Groundwater assessment using remote sensing and GIS in a rural groundwater project in Ghana: lessons learned. Hydrogeol J 4:40-49

Sangay G, Thuong VT, Gunda GKT, Kannaujiya S, Chatterjee SR, Champatiray PK (2020) Groundwater potential zones using a combination of geospatial technology and geophysical approach: case study in Dehradun, India. Hydrol Sci J 65(2):169-182. https ://doi.org/10.1080/02626667.2019.1688334

Sasaki Y (1992) Resolution of resistivity tomography inferred from numerical simulation. Geophys Prospect 40:453-463

Shahid S, Nath SK, Roy J (2000) Groundwater potential modeling in soft rock area using GIS. J Remote Sens 21:1919-1924

Shailaja G, Kadam AK, Gupta G, Umrikar BN, Pawar NJ (2019) Integrated geophysical, geospatial and multiple-criteria decision analysis techniques for delineation of groundwater potential zones in a semi-arid hard-rock aquifer in Maharashtra, India. Hydrogeol J 27:639-654. https://doi.org/10.1007/s1004 0-018-1883-2
Singh AK, Panda SN, Kumar KS (2013) Artificial groundwater recharge zones mapping using remote sensing and GIS: a case study in Indian Punjab. Environ Earth Sci 62(4):871-881

Solomon S, Quiel F (2006) Groundwater study using remote sensing and geographic information system (GIS) in the Central highlands of Eritrea. Hydrogeol J 14:729-741

Srivastava PK, Bhattacharya AK (2006) Groundwater assessment through an integrated approach using remote sensing, GIS and resistivity techniques: a case study from a hard rock terrain. Int J Remote Sens 27(20):4599-4620

Storey BC (1995) The role of mantle plumes in continental breakup: case histories from Gondwanaland. Nature 377:301-308

Talabi AO, Tijani MN (2011) Integrated remote sensing and GIS approach to groundwater potential assessment in the basement terrain of Ekiti area southwestern Nigeria. RMZ Mater Geoenviron 58(3):308-328

Thakur JK, Singh SK, Ekanthalu VS (2017) Integrating remote sensing, geographic information systems and global positioning system techniques with hydrological modeling. Appl Water Sci 7:15951608. https://doi.org/10.1007/s13201-016-0384-5

Todd D (1980) Groundwater hydrology, 2nd edn. Wiley, New York, pp 111-163

Todd D, Mays L (2005) Groundwater hydrology, 3rd edn. Wiley, Hoboken, pp 111-163

Tweed SO, Leblanc M, Webb JA, Lubczynaski MW (2007) Remote sensing and GIS for mapping groundwater recharge and discharge areas in salinity prone catchments, southeastern Australia. Hydrogeol J 15(1):75-96

Publisher's Note Springer Nature remains neutral with regard to jurisdictional claims in published maps and institutional affiliations. 